\title{
As galinhas incontáveis. Tupis, europeus e aves domésticas na conquista no Brasil
}

Felipe Ferreira Vander Velden

\section{(2) OpenEdition}

\section{Journals}

Edição electrónica

URL: https://journals.openedition.org/jsa/12350

DOI: 10.4000/jsa. 12350

ISSN: 1957-7842

\section{Editora}

Société des américanistes

\section{Edição impressa}

Data de publicão: 31 dezembro 2012

Paginação: 97-104

ISSN: 0037-9174

\section{Refêrencia eletrónica}

Felipe Ferreira Vander Velden, «As galinhas incontáveis. Tupis, europeus e aves domésticas na conquista no Brasil », Journal de la Société des américanistes [En ligne], 98-2 | 2012, mis en ligne le 10 décembre 2015, consulté le 02 septembre 2022. URL : http://journals.openedition.org/jsa/12350 DOI : https://doi.org/10.4000/jsa. 12350 


\title{
AS GALINHAS INCONTÁVEIS. TUPIS, EUROPEUS E AVES DOMÉSTICAS NA CONQUISTA NO BRASIL
}

\author{
Felipe Ferreira VANDER VELDEN *
}

Este artigo reflete sobre as relações entre os grupos Tupi no litoral da América portuguesa e as galinhas domésticas introduzidas nos primeiros contatos. Utilizando os registros, produzidos pelos cronistas coloniais, da presença destas aves em aldeias Tupi nos séculos XVI e XVII, e cotejando estas informações com o conhecimento acumulado tanto sobre os Tupi coloniais como sobre populações Tupi contemporâneas, espera elucidar algumas questões relativas à posição das galinhas domésticas nestas cosmologias, bem como discutir um complexo de relações que conectava aldeias indígenas e núcleos coloniais nos dois primeiros séculos da conquista. Sugere-se que as galinhas correspondem a uma categoria intermediária de animal, situada entre os animais domésticos (pets) e os animais familiarizados (wild pets). Discute-se, ainda, a possibilidade de que esta característica das aves domésticas introduzidas tenha criado uma rede de trocas destinadas ao abastecimento dos estabelecimentos coloniais e dos viajantes na América portuguesa. [Palavras chave: galinhas domésticas, arte plumária, Tupinambá, Brasil colônia, etnologia.]

Les poules innombrables: Tupi, Européens et oiseaux domestiques pendant la Conquête du Brésil. Cet article propose une réflexion sur les relations entre les groupes tupi du littoral de l'Amérique portugaise et les poules domestiques introduites lors des premiers contacts. En s'appuyant sur les registres coloniaux, concernant la présence de ces oiseaux dans les villages tupi aux $\mathrm{XVI}^{\mathrm{e}}$ et $\mathrm{XVII}^{\mathrm{e}}$ siècles, puis en comparant ces informations avec la connaissance accumulée sur les Tupi coloniaux et sur les Tupi contemporains, nous allons proposer quelques réponses aux questions relatives à la position des poules dans les cosmologies tupi. Nous aborderons également les relations entre hameaux indigènes et hameaux coloniaux pendant les premiers siècles de la conquête. Les poules seront considérées comme une catégorie intermédiaire d'animaux, entre animaux domestiques (pets) et animaux apprivoisés (wild pets). On pose l'hypothèse que ces oiseaux domestiques ainsi définis constituent le moteur d'un réseau d'échanges ayant pour objectif l'approvisionnement des établissements coloniaux et des voyageurs

* Departamento de Ciências Sociais, Universidade Federal de São Carlos (UFSCar), via Washington Luís, Km 235, Caixa Postal 676, 13565-905 São Carlos, São Paulo, Brasil [felipevelden@yahoo.com.br].

Journal de la Société des Américanistes, 2012, 98-2, pp. 97-140. C Société des Américanistes. 
dans l'Amérique portugaise. [Mots-clés : poule domestique, plumasserie, Tupinambá, Brésil colonial, ethnologie.]

Unlimited chickens: Tupians, Europeans and domestic fowl in the conquest of Brazil. This article explores the interaction between the Tupi-speaking indigenous peoples in coastal Portuguese America and the domestic chicken introduced in the first years of the conquest. Several notes produced by colonial observers during the 16th and 17th centuries mentioned chicken living in Tupi villages. These reports, allied to the historical, ethnographic and ethnological knowledge accumulated on the colonial Tupians and other contemporary Tupi-speaking groups, would help us elucidate some questions about the cosmological meanings of domestic chickens among Tupians, as well as discuss a complex network which connected native and colonial villages in the first 200 years of the conquest. I suggest that chicken were an intermediary animal category situated between domesticated animals (pets) and tamed animals (wild pets). I also argue that this characteristic of domestic fowl introduced by Europeans was a trigger for an exchange network that provisioned the first colonial villages and travelers in Portuguese America with food supplies. [Key words: domestic chicken, featherwork, Tupinamba, Colonial Brazil, ethnology.]

" Gallinarum numerus sine numero ». (Barléu 1974 [1647], p. 133) « Em troca de um anzolzinho, os tolos entregam cinco ou seis galinhas ».

(Zweig 1999, p. 150)

\section{INTRODUÇão}

A introdução, difusão, aclimatação e adoção de espécies de plantas e animais em regiões diferentes de seus habitats originais é questão que preocupa, há algum tempo, as ciências naturais e os ambientalistas. Nos últimos anos, o problema tem sido objeto de análises históricas mais detalhadas (ver, por exemplo, Dorst 1973; Crosby 1972, 1991 e 2002; alguns dados também em Diamond 1999 e 2005; e Dean 2004); estas, no entanto, apresentam escopo muito amplo, propondo grandes panoramas da dispersão de espécies animais e vegetais ao redor do planeta ou por alguns grandes ecossistemas; tais análises, em sua maioria, não se debruçam sobre as minúcias históricas destes complexos processos sócioambientais - oferecendo, quase sempre, apenas breves comentários acerca dos impactos sociais e culturais do fenômeno -, restringindo-se, praticamente, as suas conseqüências econômicas e, sobretudo, ecológicas ${ }^{1}$. Em geral, sabemos algo sobre o « artesanato de comunidades biológicas artificiais » (como definido por Dorst 1973, p. 270; ver também Teixeira 2004) produzidas, intencionalmente ou não, pelos homens, mas muito pouco sobre as maneiras específicas como diferentes populações humanas, diretamente afetadas por esta circulação deliberada ou acidental de espécies naturais, percebem e se relacionam com tais 
alterações, nas áreas em que habitam e nas espécies animais e vegetais com as quais se relacionam, ou passam a ter de se relacionar.

Viajando na companhia dos navegadores que vasculharam mares e terras por todo o globo a partir do século $\mathrm{xv}$, os animais domésticos europeus foram, certamente, os mais importantes agentes da enorme " difusão biológica da Europa »(Crosby 2002). Entre as espécies mais significativas desta dispersão estava a galinha doméstica (Gallus domesticus, Linnaeus 1758) ${ }^{2}$, cuja expansão por todo o planeta e importância para a economia mundial são conhecidas de todos nós. Domesticada no sudeste da Ásia (China, Índia, Tailândia ou Península Malaia, não há consenso quanto ao local) - assim como outras espécies domésticas « caseiras », tais como cães e porcos (Gilmore 1997, p. 251; Simoons 1974, p. 559) - talvez mais de 8000 anos atrás, teria chegado à Europa por volta do século vi a.-C. (Smith e Daniel 1975; Kiple e Ornelas 2000; Dalby 2003). Dali foi difundida pelos navegantes ibéricos, e o que nos interessa aqui é o trânsito destas aves da Europa em direção à América, em especial à América do Sul. Ao que parece, Cristóvão Colombo teria introduzido galinhas (além de cães, cavalos, bois, ovelhas, cabras e porcos) nas Antilhas em sua segunda viagem, em 1493 (Nordenskiöld 1922, p. 1; Crosby 1991, pp. 77-79). A frota de Pedro Álvares Cabral que aportou no que é hoje o litoral sul da Bahia em 1500 trazia galinhas (Gilmore 1997, p. 251), e parece certo que alguns exemplares destas aves permaneceram com os índios nas terras recém-descobertas, inclusive na companhia dos degredados que Cabral teria deixado no local (Nordenskiöld 1922, p. 2); não me importa, contudo, uma reconstrução detalhada das trajetórias de introdução e difusão das galinhas domésticas européias na América portuguesa (se é que a documentação existente permite tal empreitada) ${ }^{3}$; cumpre ressaltar, apenas, que uma vez introduzida nas Américas, a galinha « espalhou-se rapidamente e tornou-se parte da economia aborígene [sic] » (Gilmore 1997, p. 251).

É este « tornar-se parte da economia aborígene » o objeto deste ensaio. No que se segue, procuro arrolar testemunhos da existência de galinhas domésticas originárias do continente europeu entre as populações indígenas no litoral da América portuguesa dos séculos XVI e XVII. Decidi concentrar-me nas populações de língua Tupi que se espalhavam, de forma mais ou menos homogênea, pela costa oriental da América do Sul quando da conquista em 1500 (Fausto 1992), em função da quantidade e da qualidade dos relatos quinhentistas e seiscentistas existentes (Fernandes 1975). Tais documentos podem oferecer um panorama dos primeiros momentos da introdução e expansão desta importante espécie doméstica entre as sociedades indígenas nas terras baixas sul-americanas. É evidente que, dada a extensão do território ocupado pelos Tupi quinhentistas, as experiências históricas de cada um dos grupos alcançados pelos colonizadores europeus tenham sido muito diversas, mesmo no tocante à introdução de novos objetos e seres humanos e não-humanos. Não obstante, as recorrências dos 
relatos - a não ser que expressem uma intensa circulação de textos e reprodução de idéias - parecem sugerir que não só a regularidade do conjunto de equipamentos, artefatos e animais trazidos com os colonizadores, mas também a homogeneidade da cultura Tupi difundida pelo litoral oriental sul-americano - que, ao que parece, havia completado a ocupação da imensa região poucos séculos antes (Fausto 1992, pp. 381-384) - permitem uma análise coerente e proveitosa do conjunto textual.

Meu objetivo, a partir desta investigação dos relatos históricos, é oferecer sugestões que levem a uma melhor compreensão de duas questões. Primeiro, gostaria de refletir sobre o fenômeno da incorporação de espécies invasoras, exóticas ou exógenas nos universos sociais e culturais das sociedades Tupi na costa. Como tal, pretende ser uma contribuição aos estudos micro-históricos e antropológicos sobre as trajetórias - tanto geográficas quanto simbólicas - das espécies introduzidas pelos colonizadores europeus nas Américas. E, por outro lado, interroga também as trajetórias de artefatos no universo colonial, uma vez que este trânsito simbólico foi-me sugerido, sobretudo, por estudos que indicam que os famosos mantos Tupinambá, de penas vermelhas de guará (Eudocimus ruber, Linnaeus $1758^{4}$ ), constantes da coleção do Royal Kunstkammer (depositada no Departamento de Etnografia do Nationalmuseet em Copenhagen, Dinamarca), foram confeccionados com « penas de guará e possíveis penas de papagaios e plumas tingidas de galinhas » (Due 2002, p. 192). A origem e a datação destes artefatos ainda não estão plenamente estabelecidas, mas é provável que sejam originários do nordeste do Brasil ocupado pelos holandeses, tendo sido parte de uma coleção doada por Johan Maurits van Nassau-Siegen ao Rei Frederik III, da Dinamarca, na segunda metade do século XVII (ibid., p. 187) ${ }^{5}$. Nesse sentido, a presença de penas de galinha artificialmente coloridas nestas peças de rara beleza ${ }^{6}$ sugerem sentidos múltiplos: em primeiro lugar, a certeza de uma confecção em contexto colonial, em que as galinhas domésticas já faziam parte do cotidiano do grupo (ou grupos) que utilizavam suas penas ${ }^{7}$; segundo, que as penas de galinha se mostraram adequadas para a produção destes adornos cuja importância ritual transparece em vários cronistas, tanto mais que sabemos que as penas rubras dos guarás eram particularmente apreciadas pelos Tupi costeiros, e tidas por eles como suas « preciosidades » (como diz Hans Staden 1999 [1557], pp. 101, 113); terceiro, que a utilização de penas de galinha pintadas nestes artefatos plumários, se informam sobre as técnicas artesanais empregadas, e sobre os sentidos atribuídos pelos grupos indígenas a esta espécie de pássaro introduzida pelos colonizadores, também dizem alguma coisa sobre o estatuto destas peças na apreciação dos europeus nos séculos XVI e XVII, para quem penas de galinha não eram novidade, mas que se convertiam em algo excepcional se entrelaçadas a magníficas penas vermelhas em adereços tão exóticos. Teriam sido estes mantos com penas de galinha confeccionados para uso ritual? Ou terão sido tão-somente peças decorativas, 
circulando em uma rede crescente de peças provenientes de populações primitivas, e trazidas de cantos remotos do globo para o espanto e a admiração dos europeus? Tais artefatos dirão mais sobre os Tupi litorâneos ou sobre os europeus que deles adquiriam as peças guardadas ciosamente por uns poucos museus na Europa?

Esta última observação introduz a segunda questão sobre a qual quero me debruçar, qual seja, a natureza da circulação de espécies animais (ou de certas partes de seus corpos, como as penas) entre europeus e índios nos primeiros momentos da ocupação colonial no Brasil. A análise dos relatos existentes sobre estas transações, nos séculos XVI e XVII, parece sugerir que elas eram algo diversas dos intercâmbios envolvendo manufaturas e outros objetos inanimados, e que a difusão destas criaturas vivas entre as populações indígenas na costa deveu-se menos ao escambo direto do que a um processo paulatino e contínuo de difusão e adoção, algo semelhante aquilo que Crosby (2002) denominou como « imperialismo ecológico ».

É possível que a maior parte das questões acima evocadas jamais venha a ser respondida, e este artigo pretende, apenas, refletir sobre elas e, quiçá, sugerir algumas possibilidades interpretativas. Não obstante, antes de partirmos para os registros uma observação preliminar se mostra fundamental. Uma dificuldade significativa na reconstrução da história da difusão das galinhas domésticas européias (Gallus gallus domesticus ou Gallus domesticus) pelo continente americano está na identificação das espécies registradas pelos observadores nos séculos XVI e XVII. Se parece certo que os europeus introduziram nas Américas as galinhas domésticas, também é fato que, em seus textos, designaram como " galinhas » uma variedade de aves galiformes inexistentes na Europa, mas comuns nos ecossistemas sul-americanos e nas aldeias indígenas (muitas como xerimbabos); assim, mutuns, jacus e outros pássaros eram frequentemente referidos como "galinhas do mato », "galinhas silvestres » ou "galinhas bravas » por vários destes autores (Catharino 1995, pp. 214-215). Donkin (1989, pp. 21, 67-69, 83-87) elenca diversos relatos históricos nos quais a identificação das aves é virtualmente impossível em função da presença de numerosas espécies em um mesmo contexto ecológico, muitas delas semelhantes a espécies conhecidas pelos europeus e frequentemente confundidas com elas; quanto à presença de aves nas aldeias indígenas, o mesmo autor fornece uma pequena amostra de sua variedade (ibid., p. 15). Uma das espécies nativas mais confundidas pelos observadores quinhentistas e seiscentistas era a chamada « galinha araucana » (também « chilena », « crioula » ou « pré-hispânica », Gallus inaurus ou Gallus castelloi), um galináceo difundido ${ }^{8}$ entre as populações indígenas no Chile, Pampa argentino e bacia Platina (Sick 1984, pp. 239-240; Garavaglia 1999, p. 34).

Sick, autor de um dos mais completos compêndios de ornitologia brasileira, corrobora estas informações. Para Sick, as «galinhas » mencionadas pelos 
europeus na América do Sul na primeira metade do século XVI não são galinhas domésticas européias, mas diversas espécies da família Cracidae (ordem Galliformes), que inclui aracuás, jacus, jacutingas e mutuns, entre outros (Sick 1984, p. 239). Como exemplo, Sick afirma que as « galinhas » observadas pelo viajante bávaro Ulrich Schmiedel em aldeias indígenas na América meridional, entre 1534 e 1554, eram provavelmente cracídeos, talvez jacus (ibid., p. 105). O renomado ornitólogo sugere, ainda, que embora registradas em aldeias indígenas a partir da segunda metade do século XVI, a galinha doméstica européia ter-se-ia espalhado muito lentamente pelo interior do Brasil, sendo ainda pouco comum nos anos de 1950 (ibid., p. 239)! Neste sentido, a opinião de Helmut Sick contrasta com as descobertas de alguns historiadores que destacam a rapidez com que as galinhas domésticas difundiram-se pela América do Sul (Saignes 1999, p. 108). Garavaglia (1999, p. 34), por exemplo, afirma que, já em 1519, os textos europeus provavelmente se referem às galinhas introduzidas, mesmo quando parecem referir-se à galinha araucana; informa, ainda, que as galinhas européias teriam chegado ao Paraguai já nos anos de 1530.

Outra dificuldade está na consideração das chamadas Galinhas-d'Angola (Numida meleagris galeata, Pallas 1767), também conhecidas por Galinhas-daGuiné (e outros muitos nomes, Nomura 1996, p. 56). Não há dúvidas de que esta espécie, nativa da África, foi trazida para a América pelos europeus, introduzida nas Antilhas em 1508 e no Brasil logo nos primórdios da colonização portuguesa (Teixeira 1998, I, p. 45), segundo Sick (1984, p. 240) proveniente das ilhas de Cabo Verde. É Curioso notar que esta espécie foi bastante comum na Europa - a partir de exemplares introduzidos por gregos e romanos - até o seu completo desaparecimento naquele continente com a desagregação do Império de Roma no século V; somente nos séculos XV e XVI navegadores lusitanos levarão exemplares da Galinha-d'Angola para Portugal, de onde teriam vindo para o Brasil e se tornado aves domésticas relativamente comuns já em meados do século XVII (Teixeira ibid.). Embora conhecidas pelos portugueses, aparentemente foram consideradas exóticas pelos holandeses em Pernambuco do século XVII, o que explicaria a presença de representações desta ave - entre papagaios, araras e mutuns - em coleções de pinturas holandesas que buscavam retratar a diversificada fauna local (ver reproduções das pinturas em Teixeira ibid., pp. 4647; 1998, II, p. 43; 2004, pp. 274-276) ${ }^{9}$. Não sabemos com certeza, entretanto, se os observadores holandeses consideravam a galinha-d'Angola uma espécie nativa ${ }^{10}$, e tampouco existem registros da existência destas aves em aldeias indígenas no litoral oriental do Brasil. De todo modo, a presença desta espécie africana em terras americanas sugere que os intercâmbios entre biotas são mais complexos, e seu estudo não deve estar restrito ao tema da expansão européia.

Não obstante, por mais que possam ter sido confundidas com espécies de aves nativas da América tropical (ou com as galinhas-d'Angola, também introduzidas), os relatos quinhentistas e seiscentistas deixam claras a rápida 
disseminação e a presença maciça das galinhas domésticas de origem européia entre as populações indígenas de língua Tupi-Guarani nos litorais da América Portuguesa. Adotadas com sucesso, contudo, sua importância não parece ter residido tanto nas " economias aborígenes", tal como citado acima, se entendemos estas no seu sentido estrito, de produção de meios de existência material. $\mathrm{O}$ que os relatos parecem descrever, se adotamos uma perspectiva mais ampla, é que as galinhas tornaram-se parte de uma economia simbólica diversa daquela dos europeus, fundada sobre a adoção destas aves mais como animais de estimação (pets) do que como meios de subsistência. Ou seja, os Tupi no litoral não parecem ter adotado a criação sistemática de galinhas para o consumo, a não ser que consideremos um certo " micro-sistema econômico inter-étnico ", no qual as galinhas nascidas e crescidas nas aldeias vinham a ser consumidas pelos europeus em contato com elas. Mais do que isto, sugiro, estas aves exóticas ou exógenas foram incorporadas ao cotidiano destes grupos indígenas em uma posição que pode ser descrita como intermediária, nos nossos termos, entre os animais amansados (ou familiarizados) e os animais domesticados.

Hoje, as galinhas domésticas, trazidas para o continente americano pelos primeiros navegadores europeus, são comuns na vida diária de numerosas aldeias indígenas no Brasil. Elas parecem ter se tornado parte deste cotidiano muito rapidamente, pelo menos entre os grupos de língua Tupi então na costa brasileira: sugere-o a presença de penas de galinha na confecção dos belíssimos mantos de plumas Tupinambá, um dos adornos plumários de maior importância ritual para estas populações.

É válido observar que, se já nos séculos XVI e XVII os Tupinambá na costa brasileira estavam colorindo artificialmente penas de galinhas para a confecção destas peças de rara beleza, qual é a razão para considerarmos, hoje, como espúrio ou inautêntico, o uso das penas destas aves nos adornos plumários e outros objetos de certas populações indígenas, notadamente aquelas consideradas « emergentes » ou « resistentes » (Pacheco de Oliveira 1999; Barbosa 1999) ${ }^{11}$ ? Este trabalho espera, então, contribuir também para uma reconsideração das noções amplamente aceitas a respeito da « autenticidade » ou « indianidade » de certos grupos indígenas no Brasil. Com efeito, as penas de galinhas domésticas utilizadas, por muitas destas sociedades, na confecção de sua arte plumária e outras peças artesanais funcionam, em larga medida, como índice de sua inautenticidade frente aqueles grupos indígenas que dispõem de farto suprimento de coloridas plumas de araras, papagaios e outras aves. Ora, as penas de galinha (e de outras aves introduzidas) utilizadas por estes grupos indígenas são o índice de sua distintividade em relação aos não-índios e a outras populações indígenas ${ }^{12}$; os índios " emergentes », hoje, indigenizam as penas de galinha, do mesmo modo que, quatrocentos ou quinhentos anos atrás, os Tupinambá estavam indigenizando as mesmas penas, ao colorirem-nas de vermelho, fixando-as naqueles que serão considerados dos mais belos exemplos das 
técnicas plumárias sul-americana. Passemos, pois, aos cronistas, muitos deles contemporâneos desta arte.

\section{« As gallinhas São infinitas... "}

Que as galinhas domésticas comuns, ou européias, não são nativas do Brasil, e foram introduzidas pelos navegadores que por aqui aportaram a partir do século XVI, parece certo (Nordenskiöld 1922, pp. 1-12). Caminha é preciso ao afirmar que os índios que « descobre » em 1500 « não lavram, nem criam. Não há aqui boi, nem vaca, nem cabra, nem ovelha, nem galinha, nem qualquer outra alimária, que costumada seja ao viver dos homens » (Caminha 1999 [1500], p. 54). E a Relação da viagem do capitão francês Paulmier de Gonneville - que, ao que tudo indica, esteve por seis meses entre os Carijó no sul do Brasil-, tampouco faz menção a estas aves (Perrone-Moisés 1992). Goneville esteve no Brasil em 1503 e, certamente, teria relatado a presença de galinhas domésticas, caso existissem, uma vez que seu relato - assim como o de Caminha - é riquíssimo e detalhado na descrição das aves que encontrava. De fato, além do trânsito intenso de aves exóticas da América para a Europa, todos os relatos sobre a América portuguesa dos séculos XVI e XVII dedicam substancial atenção às aves, talvez porque seu exotismo - assim como suas penas coloridas e brilhantes fossem já materiais altamente apreciados na Europa ${ }^{13}$ (Schindler 2001; Dean 2004, pp. 66-67).

As galinhas não estavam por aqui, mas logo chegariam. Pressionados pela perigosa escassez de alimentos durante as longas travessias marítimas, os navegadores europeus desde cedo começaram a levar, nas suas viagens, animais domésticos vivos:

O amanhecer no navio, assim como na cidade, podia ser anunciado pelo canto de um galo das capœiras do capitão, do piloto, do mestre ou do contramestre, que tinham entre seus privilégios a permissão de embarcarem galinhas - principalmente para curar os doentes - além de cabritos, porcos e até vacas. (Miceli 1998, p. 137)

Deste modo, chegaram ao Brasil, já com a expedição de Pedro Álvares Cabral. Episódio pouco conhecido da famosa carta de Pero Vaz de Caminha, o encontro entre portugueses e índios no que é hoje o litoral meridional da Bahia foi, também, uma apresentação mútua de novas espécies do mundo natural; não só os marinheiros lusitanos maravilharam-se com papagaios, araras e tucanos, mas coube aos índios na costa, também, o estranhamento diante de novas criaturas. Diz Caminha, do pequeno grupo de índios recebidos a bordo por Cabral:

Mostraram-lhes um papagaio pardo que o Capitão traz consigo; tomaram-no logo na mão e acenaram para a terra, como quem diz que os havia ali. Mostraram-lhes um 
carneiro: não fizeram caso. Mostraram-lhes uma galinha, quase tiveram medo dela: não lhe queriam pôr a mão; e depois a tomaram como que espantados. (Caminha 1999 [1500], p. 37)

Ainda que « espantados », os índios parecem ter levado a galinha, e talvez tenham vindo de Cabral as primeiras aves desta espécie a ciscarem em solo brasileiro. A natureza do medo dos índios merece consideração, tanto mais que, como deixa transparecer o texto de Caminha, eles mostraram interesse particular pelas aves trazidas pela expedição (entre elas um papagaio pardo, provavelmente de origem africana, que pertencia a Cabral), « não fazendo caso » do carneiro, animal aparentemente mais aberrante se temos em mente a fauna nativa das florestas do litoral da América do Sul. Voltaremos a isso. O fato é que as galinhas parecem ter prosperado nas terras conquistadas na América a partir de 1500, seja em poder dos índios, seja nas mãos de uns poucos europeus que permanecem no Brasil desde os primeiros anos da conquista. A frota de Fernão de Magalhães encontrou galinhas criadas pelos Tupinambá da baía da Guanabara em 1519 (Pigafetta apud Buarque de Holanda 1975, p. 200). Provavelmente trazidas nas embarcações que primeiro tocaram o litoral atlântico da América do Sul, circuitos de troca inter-étnicos devem ter, rapidamente, incluído galinhas entre seus itens, sem contar o fato de que os animais difundem-se de motu proprio, e podem ter chegado às comunidades indígenas antes mesmo dos contatos interpessoais.

O relato do explorador espanhol Álvar Nuñez Cabeza de Vaca, que esteve na região da bacia do Paraná-Paraguai entre 1540 e 1545 (mais ou menos na mesma época que Ulrich Schmidel) faz numerosas referências a grupos indígenas - desde os Guarani no litoral até outros grupos bem para interior, na região oriental do Chaco - que « criavam galinhas e patos », aves que eram sempre oferecidas como alimento aos espanhóis, quando estes chegavam a uma aldeia (Cabeza de Vaca 1999 [1540-1545], pp. 157, 160, 164, 213, 244-255, 275). Não sabemos se estas eram espécies nativas - patos-do-mato e galináceos sul-americanos - ou aves européias, cuja difusão pela América meridional teria acontecido de maneira espetacular. Como vimos acima, Helmut Sick suspeita que as "galinhas » de Schmidel eram exemplares nativos semelhantes às aves européias, mas uma informação de Cabeza de Vaca (1999 [1540-1545], p. 157) - « criavam galinhas e patos da mesma maneira que nós na Espanha »-a respeito dos Guarani na bacia oriental do rio Paraná pode sugerir que, de fato, as redes indígenas de comunicação e comércio - que conectavam todo o sul da América - encontradas pelos europeus nos primeiros tempos da conquista operavam de maneira eficiente na difusão das novidades introduzidas pelos invasores. Métraux (1928, p. 95), de sua parte, acredita que os primeiros exploradores do Paraguai recebiam dos indígenas "galinhas de proveniência européia ». Nóbrega (2006 [1549], p. 33), em carta de 1549, referindo-se aos Carijó no sul das terras portuguesas na América, relembra a criação de « gansos » (Cairina moschata) por estes índios, 
além da abundância de « bois, vacas, ovelhas, cabras e galinhas » que « dão na terra e há deles muita cópia ».

Tendo chegado, pois, as galinhas multiplicaram-se de maneira notável, e espalharam-se rapidamente pelo território. Uma das primeiras espécies européias a se difundir pelo Brasil, a galinha aparentemente já era comum nos povoados costeiros portugueses e nas aldeias Tupinambá por volta de 1550 (Metcalf 2005, pp. 128-129); sua penetração no interior parece ter sido espetacular, a crer no testemunho de Oviedo y Valdés, que registra os Omágua no alto Solimões já em 1556 de posse de galinhas de origem européia (apud Métraux 1928, p. 95); e no relato do padre Acuña (1994 [1639], p. 93), que registrou que os nativos, no rio Amazonas, " criam em suas casas galinhas das nossas, cuja semente desceu do Peru e, de aldeia em aldeia, foi se espalhando por todo o rio $»{ }^{14}$.

Também Fernão Cardim, cento e vinte e cinco anos após a chegada de Cabral, espanta-se: «As gallinhas são infinitas, e maiores que no Reino, e pela terra ser temperada se criam bem, e os índios as estimão, e as crião por dentro do sertão trezentas e quatrocentas léguas » (Cardim 1980 [1625], p. 58). E, um pouco mais tarde, Gaspar Barléu, em Pernambuco ocupado pelos holandeses - «É sem número o número das galinhas, em razão do clima temperado. São ávidamente procuradas tanto pelos índios quanto pelos portugueses, e criam-se com grande cuidado » (Barléu 1974 [1647], p. 139) - assim dando crédito ao comentário de Denis (1980 [1838], p. 86), revendo a história do Brasil dois séculos depois: «A galinha comum foi trazida da Europa, e tem-se multiplicado em todas as províncias ».

Estes são testemunhos já tardios. Embora Hans Staden, em seu relato, não mencione galinhas entre os Tupinambá que o mantiveram cativo, ele reconhece o valor das penas de pássaros para estes índios, que são, segundo o soldado bávaro, « sua riqueza ». As penas de galinha parecem ser rapidamente inseridas nesta « economia plumária », como nos conta Léry, falando dos Tupi no Rio de Janeiro, de longe o testemunho mais completo:

Além disso, criam os nossos americanos grande quantidade de galinhas comuns, cuja raça foi introduzida pelos portugueses. Depenam as brancas e com instrumentos de ferro (antes de os terem com peças aguçadas) picam bem miúdo o frouxel e as penas pequenas; depois fervem e tingem de vermelho com pau brasil e esfregando o corpo com certa resina apropriada grudam-nos em cima, ficando assim vermelhos e emplumados como pombos recém-nascidos. (Léry 1980 [1578], pp. 114-115)

Será esta a origem das penas de galinha artificialmente tingidas empregadas na confecção dos mantos, acima evocada? Voltaremos a esta questão adiante. Depois das plumas, Léry oferece-nos ainda mais detalhes da relação dos Tupi costeiros com estes pássaros trazidos pelos navios europeus. Vale a pena transcrever todo o trecho: 
Antes de mais nada direi que eles [os Tupinambá] possuem em grande abundância essas galinhas grandes, ditas da Índia e que eles denominam arinhan-assú; os portugueses introduziram no país as galinhas comuns, antes desconhecidas e a que os selvagens chamam arinhan-mirim. Como já disse, embora apreciem as galinhas brancas, por causa das penas que tingem de vermelho e com as quais se enfeitam, não as comem. E como pensam que os ovos, arinhan-ropiá são venenosos, não só ficavam muito admirados em nos ver sorvê-los mas ainda diziam que por falta de paciência para deixá-los chocar praticávamos a gulodice de comer uma galinha inteira num ovo. Não dão importância às suas galinhas, tal qual se tratasse de aves silvestres; deixam-nas andar por onde querem e elas chocam nos matos e moitas de sorte que as mulheres selvagens não têm o trabalho de criar os pintos com gema de ovo como se faz entre nós. $\mathrm{E}$ as galinhas se multiplicam entretanto de tal forma nesse país que há localidades ou aldeias pouco freqüentadas pelos estrangeiros, onde, por uma faca do valor de um carolus [moeda antiga] se tem uma galinha da Índia; e por uma de dois liards [moeda antiga], ou por cinco ou seis anzóis se obtêm três a quatro galinhas pequenas comuns. (Léry 1980 [1578], pp. 147-148)

Quanto ao modo como os Tupi na costa denominavam e tratavam as galinhas européias - outra questão a ser abordada na próxima seção deste artigo - o missionário francês D’Abbeville, então no Maranhão, parece ecoar Léry:

Quanto aos pássaros domésticos, há muitos como sejam galos e galinhas da Índia, chamados arainhã, que aí muito se multiplicam, muitas galinhas comuns, mui parecidas com as nossas, a que dão o nome de uirá-sapucaí, quando já tem posto cinco a seis ovos. Chocam seus ovos em todo o tempo, e eis a razão de sua multiplicação. (D’Abbeville 2002 [1614], p. 232)

E, adiante no seu texto, referindo-se às habitações dos índios, esclarece outro detalhe interessante, ainda que intrigante: « Muitos índios têm na frente de suas casas grandes galinheiros, uiraro-cai, onde há galinhas comuns » (D’Abbeville 2002 [1614], p. 270).

O testemunho de André Thevet, em 1556, é também muito semelhante ao de Léry e, de certo modo, contradiz os relatos de Cardim e Barléu quanto à multiplicação espetacular das galinhas nas aldeias:

Os selvagens não criam, em torno de casa, animaes domésticos, a não ser algumas gallinhas; mas estas aves são assim mesmo raras e só existem em certos lugares, trazidas pelos portugueses (pois antes não tinham dellas nenhum conhecimento). Todavia, não dão muito apreço a essas criações, pois, por uma faquinha de nada, quem quiser pode obter duas das aves. E de modo algum as comem as mulheres, mostrando até desagrado quando vêem os franceses servir-se, nas refeições, de quatro ou cinco ovos (que chamam arignane), pois dizem que cada ovo corresponde a uma gallinha, isto é, alimento sufficiente para satisfazer a dois homens. (Thevet 1944 [1556], pp. 266-267, grifo no original) 
Intrigante, da mesma forma, é o apontamento de frei Vicente de Salvador, escrevendo na Paraíba, única menção ao consumo de galinhas por um índio (ainda que não fique claro se se trata realmente de galinhas domésticas européias):

Tinha mandado criar muitas galinhas, porque ele [refere-se a um índio na Paraíba] não era vilão como os outros, que comiam nas suas bodas e batismo carne de vaca e caças do mato, mas que o seu banquete havia de ser de galinha e aves de pena. (Salvador 1954 [1590-1627], p. 319)

Por fim, resta citar dois pequenos fragmentos, que também esclarecem pontos importantes a serem discutidos adiante. O primeiro deles é de Mem de Sá que, em 1570, descrevendo as escaramuças entre portugueses e Tupiniquim na capitania de Ilhéus, diz que por conta dos ataques dos europeus, os índios: " Já não ousavam estar senão pelos montes e brenhas, onde matavam os cães e galos » (Mem de Sá [1570] in Ribeiro e Moreira Neto 1992, p. 179).

Provavelmente os Tupiniquim temiam que o latido dos cachorros e o canto matutino dos galos alertassem os soldados portugueses para a presença dos índios refugiados nas matas; ou, talvez, estivessem vingando-se dos seus agressores por meio dos animais domésticos introduzidos? Pouco mais de quinze anos depois, em sua minuciosa descrição da região do Recôncavo Baiano, Gabriel Soares de Sousa aponta para outro traço marcante da relação dos Tupi costeiros com os animais domésticos: a inclusão destes no universo das atividades femininas. As mulheres Tupinambá, nos fala Soares de Sousa, além de cães, « folgam de criar galinhas e outros pássaros em suas casas » (Soares de Sousa 1987 [1587], p. 312).

Percebe-se que, em minha apresentação dos trechos dos observadores dos séculos XVI e XVII, estou priorizando um registro etnográfico, muito mais do que histórico, da relação entre os Tupi costeiros, os conquistadores europeus e as aves domésticas. De fato, é este meu objetivo, e as duas seções seguintes deverão esclarecer as razões desta preferência. É evidente que há um longo processo de disseminação das galinhas européias entre os povos Tupi no litoral sul-americano - e de adaptações e alterações das relações entretecidas tanto entre os colonizadores e os grupos indígenas quanto entre estes últimos e os pássaros introduzidos -, que se desenrola nestes primeiros duzentos anos de conquista, e que apenas uma detalhada história das rotas de dispersão das galinhas em território americano poderá, talvez, esclarecer, e que, aqui, apenas procurei esboçar. O que as fontes indicam, mesmo quando separadas, às vezes, por quase dois séculos de história da América portuguesa, parece ser um processo contínuo de difusão, explosão populacional e aclimatação/adoção das galinhas domésticas entre os Tupi costeiros e outros povos interioranos: as galinhas, que são « em grande quantidade » para Léry, serão « infinitas » para Cardim cinqüenta anos mais tarde, e « sem número » para Barléu em meados do século XVII; da mesma 
forma, as penas pintadas de galinha referidas por Léry serão, provavelmente, utilizadas na confecção dos mantos Tupinambá recolhidos pelos holandeses quase um século depois.

Existem, de fato, diversos outros testemunhos da presença de galinhas domésticas importadas da Europa entre os grupos indígenas de língua Tupi que ocupavam o litoral da América portuguesa nos séculos iniciais da conquista. Os que estão aqui reproduzidos, no entanto, nos fornecem elementos suficientes para a reflexão sobre as duas questões que sugeri na primeira seção deste artigo. Vamos a elas.

\section{« CRIAM-SE COM GRANDE CUIDADO... »}

O primeiro elemento a analisar é o nome que os Tupi costeiros atribuíram à nova espécie, questão um tanto confusa. Como vimos, tanto Léry (arinham) quanto Abbeville (arainhã) fornecem termos semelhantes ${ }^{15}$. No entanto, eles estabelecem uma diferença entre duas variedades da ave, também distinguidas, pelos dois autores, segundo os mesmos critérios: Léry distingue o que ele chama de « essas galinhas grandes, ditas da Índia» (e chamadas arinham-assu) de outras, que os « portugueses introduziram no país », que seriam « as galinhas comuns, antes desconhecidas » (que os Tupi designariam por arinham-mirim). Abbeville anota a mesma distinção, mas para ele as "galinhas da Índia » são chamadas "arainhã, que aí muito se multiplicam », ao passo que as outras, "galinhas comuns, mui parecidas com as nossas, a que dão o nome de uirásapucaí, quando já tem posto cinco a seis ovos ».

Não sei que « galinhas da Índia » são estas, mas as observações dos dois cronistas parecem sugerir que elas são nativas - seriam melhor definidas como « das Índias (Ocidentais) »? - e conhecidas pelos Tupi, ao passo que as outras são aquelas introduzidas pelos portugueses, galinhas domésticas européias. A etimologia da palavra arinham/arainhã é comentada por Plínio Ayrosa, nas suas notas ao texto de Léry (1980 [1578], p. 148); diz ser etimologia difícil, e sugere uyrá (pássaro) + ñã (correr), ou seja, " ave que corre ». Teodoro Sampaio, minucioso estudioso dos vocabulários Tupi, diz que a palavra para galinha nesta língua é sapukaîa (de « grito, gritar ») ou gûyrá (= uyrá)-sapukaîa (« ave que grita »), forma que se mantém, segundo o autor, no Nheengatu atual (Sampaio 1987, p. 167, 313).

« Ave que grita » aparece como tradução do termo nativo para galinha em algumas línguas Tupi-Guarani ${ }^{16}$. No entanto, « ave que corre »-que poderíamos entender no sentido de « ave que não voa », posto que as galinhas domésticas muito raramente levantam vôo - pode ser mais apropriado, se cremos no testemunho de Thevet (citado em Métraux 1979, p. 153), que afirma que « galos, peruas e galinhas » não são comidos pelas mulheres Tupinambá porque « julgam 
que a carne de tais aves fazem-nas envelhecer »; fazer envelhecer é, possivelmente, tornar lento, o que confere com os vários relatos (também coligidos por Métraux 1979, pp. 152-153) de espécies animais cujo consumo é evitado porque são lentos, vagarosos. A etimologia, portanto, permanece questão em aberto, mas o fragmento de Abbeville - « dão o nome de uirá-sapucaí, quando já tem posto cinco a seis ovos »- poderia sugerir alguma mudança no estatuto das aves, análogo às categorias de idade pelos quais passam homens e mulheres ao longo da vida (resumidas e comentadas em Fernandes 2003, pp. 99 sq. Sugeri algo semelhante para os cães Karitiana em Vander Velden 2010)? O balde de água fria nesta discussão, no entanto, vem de Sérgio Buarque de Holanda (1975, p. 200), que parece zombar dos esforços dos tupinólogos: para ele, o vocábulo Tupi arinham/arainhã não passaria « de uma deformação fonética da palavra portuguesa "galinha" ". Embora não mencione, Sérgio Buarque deve ter recolhido esta informação do estudo de Nordenskiöld (1922, pp. 29-30), para quem o "arignan " Tupinambá é uma variação do português " galinha ». A sugestão me parece convincente, e tenho razões pessoais para dar crédito aos dois autores ${ }^{17}$. Não obstante, a análise da classificação das aves entre os Tupi antigos - se é que existe material documental suficiente para tal empresa - poderá acrescentar novos dados à questão da nomenclatura das aves introduzidas, sobretudo quanto à posição ocupada pelas galinhas no sistema taxonômico indígena, iluminando as relações entre elas e outros seres considerados análogos, de modo a elucidar as categorias que os agrupam (por exemplo, como fizeram, para outras populações, Jensen 1985; Cuéllar e Noss 2003; também Balée 1994, para exemplo sobre plantas).

A informação anotada acima - de que as galinhas não eram comidas pelos Tupi - repete-se em quase todos os textos dos observadores quinhentistas e seiscentistas, e acompanha outros apontamentos correlatos: de que estas aves eram criadas «com cuidado », muito « estimadas» e "procuradas » pelos índios, que viviam soltas pelas aldeias e vizinhanças, que reproduziam-se sem serem molestadas e que, por isso, multiplicavam-se indefinidamente ${ }^{18}$. Tais informações são inequívocas em apontar que as galinhas foram adotadas pelos povos de língua Tupi na costa leste da América do Sul como xerimbabos, animais de estimação (pets), esta categoria que congrega certas espécies animais cujos espécimes são recolhidos na floresta e amansados, passando a viver nas aldeias, aos cuidados dos humanos (Erikson 1987, 2000; Digard 1992; Descola 1998, 1999). Os cronistas não parecem perceber as coisas deste modo, e na seção seguinte espero sugerir algumas razões para isto. Métraux (1928, p. 94; 1963, pp. 101-102), contudo, não hesita em colocar as galinhas (e cães) junto dos outros xerimbabos (pets) criados pelos Tupinambá, e as etnografias de outros povos de língua Tupi oferecem vários exemplos desta relação de cuidado, proteção e atenção para com galinhas domésticas (Ribeiro 1996, pp. 130, 391, sobre os Urubu-Kaapor; Nimuendaju 1963, p. 226, sobre os Juruna; Lévi-Strauss 1963, 
p. 300; Kracke 1978, pp. 11, 27, sobre os Tupi-Kawahib; Métraux 1963, p. 692, sobre os Omágua; Wagley 1988, p. 87, sobre os Tapirapé; Cormier 2003, sobre os Awá-Guajá; Vander Velden 2010 para os Karitiana, entre muitos outros) ${ }^{19}$.

Quanto à questão do consumo alimentar, no entanto, há dois detalhes importantes. Primeiro, os textos de Léry e de Thevet mencionam os ovos de galinhas (ropiá, ou rupiá, tupia ou supiá, « ovo » no Tupi: Sampaio 1987, p. 167) afirmando que eles jamais eram comidos porque, acreditavam os Tupinambá, comê-los era equivalente a comer uma galinha inteira. Léry informa que os índios consideravam os ovos venenosos, e por isso não os consumiam; além disso, acusavam os brancos de serem « preguiçosos », pois não esperavam surgir de um ovo uma galinha. $\mathrm{O}$ fato de que os europeus devoravam ovos com freqüência mesmo escandalizava as mulheres, diz-nos Andre Thevet, mas sua observação seguinte - que cada ovo corresponde a uma galinha e, portanto, alimento suficiente para até dois homens - nos leva a crer que não se trata - como parece ser em Léry - tanto de ser o ovo galinha em potência, a não ser que ele tenha a mesma substância, ou a mesma quantidade de substância - na falta de melhor definição - que a galinha adulta. Não há, infelizmente, dados adicionais para os Tupi costeiros sobre esta instigante questão, mas Viveiros de Castro (1986, p. 511) encontrou entre os Araweté, de língua Tupi-Guarani, certa ambigüidade em torno do consumo de ovos, que o leva a desconfiar « que o ovo seja um problema filosófico para os Araweté »; para os Araweté, continua o autor, o ovo « é uma espécie de feto » (informação que me parece perfeitamente verificável nos dois relatos sobre os Tupinambá, caso equacionemos não o feto, mas o animal após a eclosão), sendo que fetos de animais não são comidos, e fêmeas grávidas devem ser evitadas; além disso, ovos têm conotação sexual, e seu consumo equivaleria ao consumo dos órgãos genitais. Como se vê, a idéia expressa em Léry, dos ovos « venenosos » deve, antes, ser lida como um comentário sobre a interdição, baseado antes numa teoria da reprodução do que numa « química » de substâncias ${ }^{20}$.

Segundo, e mais interessante, vincula-se ao pequeno fragmento recolhido em Gabriel Soares de Sousa (e citado na seção anterior), que afirma serem as galinhas criadas pelas mulheres. $\mathrm{O}$ testemunho de Andre Thevet é muito claro neste sentido, pois afirma, explicitamente, que as mulheres « de modo algum » comiam galinhas, e manifestavam mesmo desagrado quando as viam serem devoradas pelos europeus. É possível, portanto, que aos homens fosse permitido - embora, talvez, não costumeiro - comer das galinhas e, neste caso, o insólito trecho do frei Vicente de Salvador, supracitado, poderia fazer sentido, pois se trataria de um homem. Não há maiores evidências diretas nos cronistas, mas a etnografia Tupi parece confirmar esta afirmação: Wagley (1988, pp. 87-89), por exemplo, aponta que as galinhas introduzidas entre os Tapirapé podiam ser comidas pelos « adultos do sexo masculino, mas, tal como o mutum, sua carne era considerada perigosa para mulheres e crianças, a não ser quando tratada pelo xamã ${ }^{21}$. 
Seguindo alguns de seus informantes, Wagley (1988, p. 85) informa que a carne do mutum e do pato do mato (e, provavelmente, também do inhambu e do jacu; ibid., p. 88) eram proibidas às mulheres porque carreavam a epilepsia (eangwurup), e que estas seriam mais vulneráveis a esta enfermidade, devendo o xamã afastá-la com fumaça de tabaco para tornar a carne destas aves comestível. Não parece haver informações desta natureza para os Tupi costeiros nos séculos XVI e XVII, mas estas informações parecem contradizer a assertiva categórica de Métraux, a partir de Léry e Soares de Sousa: «Observa-se, de passagem, que os animais domésticos jamais eram abatidos, e de nenhum modo constituíam reserva alimentar para a tribo » (Métraux 1979, p. 153).

Estariam os pequenos fragmentos evocados acima se referindo às galinhas no sentido amplo, nomeando, como já visto, um conjunto de espécies de aves galiformes percebidas pelos cronistas como semelhantes às galinhas domésticas (e referidas como " galinhas do mato »?). Ou, de fato, as galinhas não seriam consideradas, propriamente, como animais de estimação pelos autores dos séculos XVI e XVII?

Talvez haja alguma confusão aqui, mas o certo é que, entre os Tupi costeiros, « as aves de estimação - papagaios e araras em particular- [eram] de propriedade feminina » (Viveiros de Castro 1986, p. 662). Cabia às mulheres o cuidado com estas aves, e o que se pode inferir disso é que a relação de familiarização/filiação estabelecida com os animais domésticos colocava-os sob o domínio feminino (são abundantes, na literatura, os relatos de mulheres alimentando xerimbabos, mesmo amamentando-os; ver, por exemplo, Ribeiro 1996, p. 391; Cormier 2003); nesse sentido, os xerimbabos opõem-se diretamente aos animais caçados, inequivocamente ligados ao universo masculino, e um dos operadores lógicos importantes na relação das sociedades Tupi com os demais seres do universo (Descola 1998, 1999; Taylor 2001). Portanto, é factível supor que o laço fortemente estabelecido entre as mulheres e suas galinhas tornava o consumo destas interdito, pois flagrantemente alelofágico: «As aves de estimação não eram criadas para serem comidas » (Viveiros de Castro 1986, p. 663), mas, sobretudo, não serem comidas pelas mulheres, dedicadas « proprietárias » e, talvez, próximas demais, mesmo mães. É possível, também, sugerir que as galinhas introduzidas fossem percebidas pelos Tupinambá como diferentes - porque exóticas/exógenas - de seus animais de estimação nativos; não há maiores informações a respeito, mas o exemplo dos Guajá (Tupi-Guarani no atual oeste do Maranhão) evoca alguma ambigüidade no tratamento de animais domésticos introduzidos pelos brancos, que só são plenamente integrados ao grupo - e, portanto, tornam-se animais de estimação de forma plena - com a convivência íntima; mesmo assim, algo de sua exterioridade permanece: eles são, sempre, karaí hanima, os «animais domésticos dos brancos » (Cormier 2003, pp. 94-97). 
Ainda que sugerido aqui, este não parece ter sido o caso entre os grupos Tupi na costa, que não parecem ter destinado às galinhas tratamento ou atenção diferenciados daqueles concedidos a outras aves de estimação. Muito provavelmente, a galinha foi incorporada da mesma forma que outras espécies de pássaros, muito embora houvesse uma diferença fundamental entre uma e outras: as galinhas se reproduziam nas aldeias, ao passo que outras aves silvestres - araras, papagaios, jacus, mutuns - deveriam ser constantemente procuradas na floresta, amansadas e então incorporadas ao conjunto de animais de estimação das aldeias; elas não procriavam entre os humanos, e estes não detinham o controle de sua reprodução: elas não foram, jamais, domesticadas, no sentido preciso do termo.

Não encontrei indícios, todavia, de que esta diferença fosse percebida pelos índios, mesmo porque a reprodução das galinhas também não era rigorosamente controlada: elas simplesmente multiplicavam-se, e ficavam por ali. Seria este um indício do baixo «rendimento cultural» destas aves (Ellen 1999, p. 59), resultante, talvez, do fato de que os pássaros em geral estariam mais « distantes » dos homens do que os mamíferos (seriam menos antropomorfizáveis), e as galinhas, em especial, ao se multiplicarem excessivamente, ofereceriam ainda menores possibilidades de individuação e, portanto, de familiarização (Valeri 1992, pp. 154-155) ${ }^{22}$ ? A julgar pela importância simbólica atribuída às aves nas terras baixas sul-americanas (Jensen 1985; Giannini 1991; Reina e Kensinger 1991), tais sugestões não parecem plenamente adequadas. Não obstante, a reprodução exagerada e a superpopulação de galinhas em aldeias podem apontar direções para a reflexão, posto que neste ponto parece residir a diferença destas aves para com os demais animais trazidos da floresta.

A crer em Métraux, o modelo de relacionamento com as aves « domesticadas » nas aldeias já devia ser conhecido pelos Tupinambá como uma forma intermediária entre o amansamento e a domesticação strictu sensu: "Certain birds, such as ducks, a kind of turkey, and pigeons, may actually have been domesticated [sic]. These ducks, however, were not eaten lest their flesh cause a person to become slow » (Métraux 1963, p. 101).

Estes patos aos quais se refere Métraux são, provavelmente, da espécie Cairina moschata que, como vimos acima, é considerada a única espécie de pássaro realmente «domesticada » na América do Sul ${ }^{23}$. Note-se que a razão da interdição de seu consumo é a mesma recolhida por Thevet, e citada, alhures, por Métraux, para a carne das galinhas. Mas por que não parece haver distinções no tratamento destas aves em relação a outras espécies amansadas? Poderíamos sugerir, talvez, uma conexão entre o amansamento de animais silvestres, com sua incorporação ao universo dos humanos, e a incorporação de espécies introduzidas pelos europeus, a partir da constatação de que ambos os processos são formas daquela incessante mediação entre o exterior e o interior que caracteriza as cosmologias ameríndias (Fausto 2000, pp. 937-939). Xerimbabos são retirados 
da floresta e familiarizados: deixam o domínio potencial da afinidade, da predação e da exterioridade (definidos pela relação de caça), e são trazidos para a consangüinidade, a familiaridade, a interioridade do convívio com os humanos; modo geral de se relacionar com os seres e poderes exteriores ao universo social dos grupos indígenas - animais, espíritos, inimigos (Fausto 2000, 2001; Viveiros de Castro 2002; Vilaça 1992) -, é razoável supor que as galinhas foram também, a seu modo, capturadas do exterior - dos brancos - e incorporadas familiarizadas - no interior das cosmologias Tupi na América colonial. Mas elas, desde o início, sempre foram muitas, e aumentavam mais e mais, como confirmam os cronistas.

Em um instigante artigo sobre as formas de comunicação entre humanos e não-humanos na Amazônia, Yvinec (2005) sugere que os animais recolhidos na floresta e amansados nas aldeias são reconhecidos como filhos do inimigo não-humano (abatido na caça) tornados consangüíneos absolutos porque não se reproduzem: a condição de seu amansamento e de sua familiarização, portanto, é a sua esterilidade; os pets (ou wild pets, como estamos tratando, aqui, os animais amansados) são incorporados como filhos não-reprodutíveis, e sua vinculação ao universo feminino ilustra sua condição: excessivamente femininos, estes animais não podem multiplicar-se, porque sem o concurso do outro sexo isso é impossível (ibid., pp. 58-59). Ora, é fácil perceber que as galinhas irrompem como algo diverso no interior deste modelo: embora convivam intimamente com os humanos, as galinhas reproduzem-se nas aldeias: são, digamos, pets reproduzíveis. Há, no entanto, uma enorme distância entre estas galinhas aldeãs e as nossas galinhas domésticas: sua reprodução acontece livremente, não é observada e nem controlada pelos humanos. É por esta razão que estou sugerindo que estas aves são algo intermediário entre os wild pets (amansados) e os pets (domesticados): introdução da fecundidade naquilo que se julga estéril, as galinhas, embora não consumidas, poderiam ser trocadas com os brancos para que estes, diante do horror dos índios, comessem-nas, no reconhecimento, talvez, de que, embora aproximadas aos wild pets, teriam, em última instância, a marca de sua origem exótica.

É possível que aí residam as ambigüidades, encontradas em vários documentos e etnografias, no tocante à possibilidade desses animais serem eventualmente consumidos nas aldeias em que são criados: com efeito, a noção de que os xerimbabos são mantidos como uma espécie de " reserva de carne » (noção antiga, presente em muitos autores, Serpell 1996, cap. 4) pode ter resistido na literatura menos em função da observação direta do uso destes seres como alimento do que da atenção aos discursos dos índios sobre sua utilização potencial como alimento; inúmeros autores relatam a inexistência de interditos específicos com respeito a estas carnes e, além disso, ouviram de seus informantes que galinhas e outros animais de terreiro podiam bem ser comidos; no entanto, jamais observaram seu consumo efetivo (Donkin 1989, p. 78; Queixalós 1993, 
pp. 78-79; Vander Velden 2010, pp. 195-202): ou seja, os índios dizem que comem, mas não comem!

Georg Grümberg, trabalhando entre os Kaiabi, afirma que os animais introduzidos pelos brancos - galinhas incluídas - só eram comidos «sob determinadas condições » (Grümberg 2004, p. 95). Sem indicar que condições são estas, entretanto, o autor nos dá uma pista para iluminar a questão da ambigüidade das galinhas: ele opõe, entre os animais introduzidos aos Kaiabi, um casal de patos mansos que não se multiplicava (isto é, não reproduzia), e que « eram tratados como animais de estimação » às galinhas, cuja carne e os ovos não eram consumidos regularmente, mas que, " em ocasiões especiais, abate-se alguma com flechas, sendo preparada como se fosse caça» (ibid., p. 106, grifo meu).

Ora, o que está em oposição, aqui, é unidade versus multiplicidade. A unidade engendra estimação ou, como queira, pet keeping; esses animais não são alimento, ao contrário, são alimentados, como filhos. E como filhos, crianças, pólo feminino por excelência, não se reproduzem, são, em certo sentido, únicos, indivíduos, e, por esta razão, portam nomes. Vejamos o que diz Ellen Basso a respeito dos pássaros, pets, entre os Kalapalo:

The itolugu-oto, " pet-owner » relationship is characterised on the human side by nurture and protection within a household, and on the avian side by lack of ifutisu (in the sense of shyness). In other words, by tameness. [...] Children and pets alike are ideally supposed to be fed, reared and kept protected within the confines of the house. (Basso 1973, p. 21, grifos no original)

Galinhas, como vimos, engendram multiplicidade ${ }^{24}$ : reproduzem-se de maneira espantosa, espalham-se pelas aldeias. Ademais, é raro que percam esta shyness de que fala Basso, permanecendo ao redor das casas ou das pessoas, mas nunca em contato íntimo. Entre os Karitiana, por exemplo, as muitas galinhas que circulam pelos terreiros só muito raramente são alimentadas, em geral ciscando o chão o tempo todo em busca de comida. Neste sentido, elas parecem, mesmo, estar em um ponto intermediário entre a caça e o amansamento/domesticidade: animais próximos mas um tanto alheios, galinhas multiplicam-se, e podem tornar-se alimento apenas em raras ocasiões; mas podem ser vendidas, trocadas ou roubadas para serem consumidas por outros que seus donos; não obstante, o signo de sua posição anômala - entre a casa e a mata - brilha claro quando o abate vem das flechas, a maneira de uma caça ${ }^{25}$.

Seria preciso investigar, evidentemente, se este tipo de posição que estou denominando intermediária é distintiva das galinhas, ou encontra-se também com outras espécies domésticas introduzidas que não freqüentam as casas das pessoas, como fazem os wild pets: porcos, cavalos, bois, cabras, ovelhas, e por aí vai. Isto, quiçá, poderia explicar o recorrente fracasso da criação de animais como alternativa para o sustento alimentar em populações indígenas nas terras 
baixas (Schröder 2003; Vander Velden 2010), pois quanto mais próximo dos humanos está o animal, mais distante da condição de caça: o que se cria não se come! Além disso, seria necessário refletir, como sugere Dalla Bernardina (1991) se a conversão do animal da casa em caça não é um mecanismo recorrente (quiçá universal, e que vale para toda e qualquer espécie) que permite a articulação entre a construção de uma relação com o animal e o seu consumo final. No entanto, algo chama a atenção no fato de que não há registros de galinhas tornadas ao estado selvagem na América do Sul: não existem galinhas ferais (Nordenskiöld 1922 , p. 13), como parece ocorrer com todos os outros animais domésticos exógenos em terras americanas. Estaremos, portanto, diante de uma espécie que entretece relações singulares com os homens? Apenas estudos aprofundados poderão demonstrá-lo.

Com tudo isto, as galinhas introduzidas com a conquista podem ter ilustrado plenamente, entre os Tupi costeiros, o mecanismo da relação entre humanos e as aves sugerido por Lévi-Strauss (1989): como uma sociedade livre, comunidade independente da dos homens, os pássaros mantêm para com estes uma relação metafórica, em que uma "sociedade» espelha a outra (são "humanos metafóricos », e esta semelhança é permitida, certamente, pela diferença significativa que separa humanos e aves no plano biológico). Vivendo junto dos homens, mas não exatamente sobre seu controle, as aves são o justo oposto, simétrico e inverso, dos cães, que estão plenamente integrados às sociedades humanas como animais domésticos (Lévi-Strauss 1989, pp. 228-232).

Mas voltemos às mulheres. As aves estavam no domínio feminino como, em geral, as atividades domésticas ou caseiras dos Tupi quinhentistas e seiscentistas (Fernandes J. A. 2003). Mas, se as mulheres não comiam as galinhas - e deixando de lado a questão se eram ou não degustadas pelos homens - como, de resto, não comiam nenhuma ave de estimação, estas eram criadas para fornecerem penas aos homens: « Mesmo que sua plumária [das aves de estimação] [fossem] enfeitar os homens, elas [eram] criadas e alimentadas pelas mulheres » (Viveiros de Castro 1986, p. 662).

Aqui, Viveiros de Castro refere-se aos papagaios e araras, mas é certo que também as penas de galinha vinham das mulheres para os homens. E aqui reencontramos o rico relato de Léry: não eram, pois, quaisquer penas de galinha utilizadas pelos Tupinambá, como afirma o autor francês, mas as penas brancas, depois de coloridas artificialmente ${ }^{26}$. O tingimento das penas sugere que a cor [vermelha] era um atributo importante para os Tupi litorâneos ${ }^{27}$, e sua predileção pelas belíssimas penas carmins do guará (Eudocimus ruber) foi atestada por vários autores quinhentistas e seiscentistas (por exemplo, Staden 1999 [1557], p. 54; Gandavo 1980 [1576], p. 113; Thevet 1944 [1556], p. 157) ${ }^{28}$. Diz Staden (ibid., p. 113) sobre os guarás que « suas penas são muito apreciadas pelos selvagens ». O que é confirmado por estudiosos mais recentes das peças que chegaram dos séculos XVI-XVII até nossos dias: "As penas de guará eram 
profusamente usadas pelos grupos Tupinambá que habitavam a costa na época da descoberta na confecção de mantos, coifas, gargantilhas e outros adornos plumários » (Ribeiro B. 1988, p. 132).

A leitura dos relatos dos séculos XVI e XVII deixa claro que as plumagens de outras espécies eram também utilizadas pelos Tupinambá, notadamente as de araras, papagaios e tucanos. Não obstante, parece que aos mantos estavam majoritariamente reservadas as penas do guará; a nota de Estevão Pinto ao texto de Thevet esclarece: « Os mantos de plumas eram feitos, sobretudo, de penas de guará (Eudocimus ruber, Linnaeus 1758), ou, na falta, com as penas de outras aves vistosas » (Thevet 1944, p. 157, grifos meus).

Penas de guará, mas não só: como já visto, o manto reproduzido em Due (2002, p. 193) inclui penas de papagaios e de galinhas, tingidas. Ao que parece, elas eram mesmo intercambiáveis, como sugere o comentário de Denis certamente recolhido em Jean de Léry - ao texto de Yves D'Evreux que trata dos guarás: «Em caso de necessidade, [as penas de guará] eram substituídas por penas de galinhas, tintas com uma preparação vermelha de ibirapitanga, ou pau-brasil » (Denis 2002 [1864], p. 413).

Note-se, além disso, que o testemunho de Léry não fala do uso das penas de galinhas na confecção dos mantos, mas recorda o uso das penugens (ou penas maiores, picadas) aplicadas por todo o corpo, depois de tingidas. E seu texto termina com um comentário de espantosa precisão etnográfica, ainda que tal teor pareça ter escapado ao cronista: diz Léry, pois, que os índios grudavam as penas nos seus corpos, "ficando assim vermelhos e emplumados como pombos recém-nascidos ».

Sabemos que o uso de penas para a decoração corporal está, via de regra, fortemente vinculado à vida ritual das sociedades indígenas, em especial se tratamos de adornos maiores e mais bem elaborados (Reina e Kensinger 1991). Entre os grupos Tupi costeiros, as penas, utilizadas em contextos rituais - « em todas as ocasiões solenes traz a cabeça ornada de um diadema de penas [...]; o manto era destinado às festas » (Denis 1980 [1838], p. 30) - destinavam-se à transformação dos homens em pássaros. Sabemos pouco dos contextos de uso dos adornos plumários Tupinambá - a maioria das referências quinhentistas e seiscentistas são vagas, falando em « festas », « cerimônias », " solenidades » ou « celebrações »-, mas uma das gravuras deixadas por Staden em 1557 (mais tarde, em 1592, retrabalhadas com mais detalhes por Theodore de Bry) mostra três xamãs Tupinambá vestindo o que parecem ser mantos emplumados caindo-lhes pelas costas, portando maracás e dançando no centro de um círculo formado por dançarinos do sexo masculino, também emplumados ${ }^{29}$. Nesta gravura podemos ver, acredita-se, os mantos em uso e, mais do que isso, sugere-nos que os xamãs eram pássaros (Furst 1991, pp. 100-102) ${ }^{30}$.

Em um artigo, que analisa minuciosamente as técnicas empregadas pelos Tupi costeiros na confecção de seus adornos plumários, confirma-se a ênfase na 
busca pela transformação dos homens em pássaros, encontrada na perfeita simetria entre as estruturas anatômicas das penas das aves e de sua fixação nos corpos das aves, e os artefatos com elas confeccionados, manifestando a exata correlação entre o significado do ritual e sua expressão material:

It is obvious that the Tupinamba people have tried to reproduce the structure of the natural plumage of the birds. To recreate this has demanded a careful selection of the feathers and downs, regarding shape and colour. Only in a few cases they have derived from the nature-like look by cutting the rims of the feathers in a serrated or angular way. (Petersen e Sommer-Larsen 1979-1980, p. 264; grifos meus)

Estas sugestões conferem com outros dados acerca do uso das penas entre os Tupinambá. Métraux (1979, p. 152), por exemplo, a partir de Yves d’Évreux, afirma que:

Os ornamentos plumários tinham, sem dúvida, significação mística. Usavam-nos os tupinambás [sic] em todas as suas festas religiosas, assim como na guerra. Diziam esses índios que as rodelas de plumas, trazidas nos rins, visavam imitar «o natural do avestruz».

A própria denominação do manto de penas, segundo Métraux (1932, p. 9), evidencia este paralelismo entre humanos e aves, a transformação daqueles em pássaros por meio do uso dos artefatos plumários que são idênticos (na cor, na riqueza, na confecção) às roupas destes: guará abucutu, "vêtement de guara », indumentária do pássaro apropriada pelos homens e utilizada em seus mais importantes rituais.

Tais conclusões são confirmadas por Viveiros de Castro (1986, pp. 660-663): no complexo de rituais realizados em torno dos inimigos capturados na guerra para serem devorados, o cativo era uma « ave rara », equacionado a um papagaio, pássaro que, amansado, era criado e alimentado pelas mulheres do grupo (assim como os cativos); de modo correlato, o executor - aquele que abria o crânio do inimigo capturado - « arremedava uma ave de rapina », um predador. Pássaros, pois, antagônicos, e se cremos no testemunho de Thevet, lá estavam os famosos mantos de penas vermelhas:

Há, demais, numerosas qualidades de pássaros, de plumagens várias, algumas vermelhas, ou de fino escarlate, outras brancas, cinzentas, ou pintadas. Dessas plumas fazem os selvagens pennachos ornamentaes de diversas sortes, com os quaes se cobrem, quando vão à guerra ou massacram seus inimigos; alguns fazem das plumas mantos ou barretes a seu modo. (Thevet 1944 [1556], p. 157)

Métraux corrobora esta informação baseado em um manuscrito inédito de Thevet, indicando que os mantos eram também utilizados pelos prisioneiros de guerra: 
Em certas ocasiões, seu [do cativo de guerra] senhor obrigava-o a passear na aldeia a fim de exibir-se a todo mundo. Também nesse momento, cobriam-no com os ornamentos plumários peculiares às grandes cerimônias tribais, inclusive com o maravilhoso manto da íbis rubra, que ainda hoje é admirado em alguns dos museus da Europa. (Métraux 1979, p. 120)

As galinhas entraram, pois, nesta economia simbólica em que as penas de pássaros eram a « riqueza » que, fornecida pelas mulheres, permitiam o pleno funcionamento da vida ritual dos grupos Tupi no litoral da América portuguesa, aí se incluindo os rituais guerreiros e antropofágicos, considerados os mais importantes ritos destas populações (Fernandes 1970; Carneiro da Cunha e Viveiros de Castro 1985). Mas estariam ali por alguma razão especial? No caso dos mantos de penas de guará, a presença de penas de galinhas domésticas poderia indicar alguma drástica diminuição na oferta das prestigiosas plumas vermelhas? ${ }^{31}$ Tendo em mente o fato de que alguns dos mantos ainda hoje existentes podem ter sido confeccionados em meados do século XVII, poderíamos, talvez, questionar se os guarás estariam tornando-se raros, muito em função da veloz destruição das florestas atlânticas da costa brasileira (Dean 2004; Olmos e Silva 2003, pp. 151-159)? Estariam estas penas rubras em processo de substituição pelas penas de galinha, muito mais abundantes em função do fato de que, diferentes de outras aves, as galinhas não precisavam ser permanentemente caçadas (como os guarás) ou amansadas (como araras e papagaios)? Estariam as penas de galinha sendo usadas porque se tornavam mais e mais disponíveis (Kensinger 1995, pp. 247-257)? Assim percebeu Alfred Métraux, nos textos coloniais:

Comme les ibis rubra commençaient à disparaître, ils en élevaient dans leurs basses-cours. Mais la quantité de plumes de guara que les Indiens pouvaient réunir ne devait pas suffire à leurs besoins, c'est probablement pour les remplacer qu'ils teignaient en rouge les plumes de certains oiseaux et des poules blanches que les Européens leur apportèrent. (Métraux 1928 , p. 142, ver também 1932, p. 10).

\section{E Sérgio Buarque de Holanda, sempre perspicaz:}

Comparados aos outros xerimbabos, que lhes [aos índios] forneciam, quando muito, as penas necessárias aos enfeites e flechas, [as galinhas domésticas] teriam a vantagem da procriação doméstica, o que lhes poupava grandes trabalhos. (Buarque de Holanda 1975, p. 202)

Não obstante, as evocações, acima transcritas, de que os mantos transformavam seus usuários em pássaros, pode nos indicar outra possibilidade: a de que o tingimento encarnado das penas de galinha as convertiam em penas de guará. Se, para os humanos, a decoração corporal - pintura, adornos plumários e de outros materiais, máscaras - transforma os corpos - porque o corpo é uma 
roupa (Viveiros de Castro 1996) - talvez o mesmo estivesse acontecendo com as aves - seja com suas penas arrancadas, seja no processo in vivo da tapiragem: pintar de vermelho as penas brancas dava uma nova " roupa » às galinhas, ou seja, um novo corpo, um corpo de guará, com sua estimada decoração rubra e brilhante. Se homens viram pássaros, alguns pássaros podem ser, também eles, transformados pela (re)decoração corporal.

Legião, as galinhas ocupavam, como vimos, esta posição intermediária entre a domesticação plena (o animal doméstico, ou pet) e o amansamento (o animal domesticado, ou o que a literatura chama de wild pet ). Esta posição aparentemente anômala pode ter sido percebida, pelos grupos de língua Tupi na costa, a partir da multiplicidade das aves, fundamentalmente enquanto oferta profícua de penas para artefatos plumários. Ao tingirem as penas brancas de galinha com tintura de pau-brasil, os Tupi tornavam estas próprias para seu uso técnico, estético e ritual. No mesmo movimento, colocavam em um mesmo processo técnico artefatos centrais no cenário dos dois primeiros séculos da conquista: pau-brasil, penas e pássaros, exóticos e introduzidos.

\section{« SÃo ÁVIDAMENTE PROCURAdAS... »}

No seu estudo, em vários sentidos pioneiro, Marchant (1943) descreve as múltiplas formas de relacionamento econômico entre europeus e povos indígenas nos primeiros oitenta anos de existência da América Portuguesa. Marchant não menciona o escambo de animais domésticos europeus: como parece evidente, este seria um detalhe menor diante do circuito que envolvia a troca de quinquilharias (ferramentas e outros objetos de ferro, tecidos, objetos de vidro, entre outras) por toros de pau-brasil, depois cativos para os engenhos de açúcar, entre outras mercadorias cobiçadas pelos portugueses. No entanto, Marchant observa que, desde os primeiros anos da conquista, e intensificando-se com a expansão dos canaviais pela costa portuguesa da América, os índios foram, sobretudo, fornecedores de víveres, de meios de subsistência, para os europeus avidamente ocupados com a exploração da madeira vermelha e, mais tarde, com a expansão da empresa canavieira (ibid., pp. 139 sq.); as colônias portuguesas na América eram, de fato, dependentes do trabalho indígena na produção de gêneros de subsistência (Schwartz 1978). Desses gêneros, destaque para a farinha de mandioca, produto indígena desde muito adotado pelos europeus na América. Mas havia, também, as galinhas.

O relato de Claude d'Abbeville, como vimos, fala da existência de « galinheiros » em uma aldeia Tupinambá no Maranhão. Não sabemos exatamente o que o religioso francês chamou de " galinheiro », mas é certo que seu texto contradiz não apenas os outros testemunhos dos séculos XVI e XVII, mas também uma ampla literatura que aponta para o fracasso da criação sistemática de animais 
entre as populações indígenas no Brasil (Schröder 2003) ${ }^{32}$. No caso dos primeiros, é forçoso observar que vários cronistas afirmam que as galinhas eram criadas soltas, reproduzindo-se livremente, "tal qual se tratasse de aves silvestres » (Léry 1980 [1578], p. 147); e que - se excetuarmos a intrigante passagem do frei Vicente de Salvador - nem as aves e nem seus ovos eram consumidos pelos Tupi costeiros. Mais ainda, como se lê no segundo trecho de Léry supracitado, os portugueses adquiriam galinhas aos índios, que estranhavam o fato de que os europeus apreciavam degustar sua carne e ovos; Marchant (1943) observa que, desde os primeiros momentos da colonização do Brasil, foram os índios, de fato, os fornecedores de alimentos, incluindo-se a carne.

$O$ texto da carta inaugural de Caminha sugere uma intensa experiência gustativa, portugueses e índios experimentando novos sabores, estranhos aos seus respectivos paladares. Observe-se, no entanto, que ao trecho acima evocado - em que uma galinha parece ser cedida aos índios - segue-se um parágrafo em que os índios rejeitam os alimentos europeus:

Deram-lhes ali [aos índios embarcados] de comer: pão e peixe cozido, confeitos, fartéis [espécie de pastel folheado], mel e figos passados. Não quiseram comer quase nada daquilo; e, se alguma coisa provaram, logo a lançaram fora. Trouxeram-lhes vinho numa taça; mal lhe puseram a boca; não gostaram nada, nem quiseram mais. Trouxeram-lhes a água em uma albarrada. Não beberam. Mal a tomaram na boca, que lavaram, e logo a lançaram fora. (Caminha 1999 [1500], p. 37)

Malograda incursão gastronômica, que ecoa a adoção das galinhas - esta ave tão apreciada nos pratos lusitanos (Câmara Cascudo 2004, pp. 571-573; Pinto e Silva 2005, pp. 42-44) - pelos índios não como alimento, mas como um tipo de animal de estimação, xerimbabo. Daí o espanto, descrito por Léry, dos índios para com os europeus, que devoravam, por pura impaciência, « uma galinha inteira num ovo $»$.

Criadores e fornecedores de galinhas - mas nunca, ressalte-se, de forma sistemática -, as aldeias indígenas na costa da América portuguesa, nas primeiras décadas da conquista, parecem ter sido, sob a ótica dos lusitanos, grandes galinheiros, assim como eram, também, grandes roçados que alimentavam engenhos e cidades e que, quando faltavam - em função, por exemplo, da rápida dizimação dos índios - provocavam mesmo fome entre os colonizadores (Schwartz 1978, p. 59). É por isso, talvez, que a introdução de animais domésticos entre os grupos indígenas em questão não fosse entendida como uma troca da perspectiva dos europeus (como ocorria no caso das ferramentas e outras miudezas), mas como uma espécie de investimento, ainda que não intencional ou ativamente procurado; tão logo perceberam que os roçados indígenas podiam produzir abundantemente, e que as galinhas ali se multiplicavam de maneira espetacular, os portugueses puderam se preocupar menos ainda com a produção 
de subsistência, dedicando-se integralmente ao pau-brasil, ao açúcar e a outros gêneros de exportação (conforme observa Marchant 1943, pp. 64 sq.). De fato, os europeus jamais cederam animais vivos nas suas trocas com os indígenas; apenas receberam-nos: primeiro aves exóticas (araras e papagaios, sobretudo), depois, galinhas. E talvez, aqui, a afirmação de Sick - de que as galinhas só muito lentamente ocuparam o interior do Brasil, sendo ainda pouco comum nos anos de 1950 (Sick 1984, p. 239) - faça algum sentido.

A dependência que os portugueses estabelecidos na colônia tinham das galinhas indígenas fica evidente em diversos relatos - como o de Léry, supracitado, e outros, posteriores - nos quais galinhas e seus ovos são comprados aos índios pelos europeus. Diz Sérgio Buarque de Holanda sobre a questão, antes de relembrar os testemunhos de Antonio Pigafetta, André Thevet e o padre José de Anchieta a respeito da aquisição de galinhas indígenas em troca de ninharias:

Da facilidade com que se naturalizavam entre os índios essas aves, é característico o fato de terem passado eles a fornecê-las a europeus mediante preços muitas vezes irrisórios. (Buarque de Holanda 1975, p. 201)

E isso até tempos muito mais recentes, pois em 1848 Hercule Florence encontrou os Apiaká (Tupi) em Mato Grosso criando galinhas para vendê-las aos viajantes (citado em Nimuendaju 1963, p. 313).

Fiquemos, pois, com o comentário de Luís da Câmara Cascudo, notável observador dos costumes do Brasil, e que sintetiza admiravelmente as conclusões deste pequeno estudo. Falando da alimentação dos povos indígenas no Brasil, e das mudanças introduzidas pelo contato, diz o folclorista potiguar:

Os galináceos não tomaram o lugar da caça de pena [...], mas foram estimadíssimos. Martius assombrava-se da rapidez com que as galinhas tinham atingido o interior das selvas mais recônditas, alheias à penetração dos «brancos». Mas, na forma de costume, o indígena não abate o animal que cria na maloca, o xerimbabo, membro honorário da família [sic]. Assim, quase não come galinhas e ovos, mas os vende. (Câmara Cascudo 2004, p. 146, grifos no original, também, p. 573)

«Par excellence, nous sommes des puissants agents géographiques parce que nous sommes des "êtres mangeants" " (Brunhes e Vallaux apud Câmara Cascudo 2004, p. 7). «Agentes geográficos », os portugueses cederam galinhas aos índios não propriamente em comércio, mas com a intenção de reproduzir, na América, um ambiente idêntico aquele de Portugal, inclusive na oferta daquilo que se podia caçar e comer. Uma forma de « imperialismo ecológico » (Crosby 2000, 2002) que foi, ao mesmo tempo, uma domesticação simbólica do ambiente natural a partir de sua transformação no familiar, corriqueiro: o Brasil à imagem e semelhança de Portugal não apenas nos povoados, mas em cada terreiro de aldeia, cheios de galinhas, porcos, cavalos e vacas. Brandão (1966 [1618]), nos Diálogos das grandezas do Brasil, observou argutamente que «Olinda semelha 
uma Lisboa pequena », farta naquelas espécies animais e vegetais tão caras ao gosto europeu: « criações sem conto de gado vacum, cabras, ovelhas, porcos, muitas aves de bolateria e outras domésticas ». Paisagens reconhecíveis por toda a parte, mesmo para aqueles homens que, deslocando-se « por dentro do sertão trezentas ou quatrocentas léguas » (como diz Cardim) podiam encontrar alento em uma familiar canja de galinha, e registrar, como Spix e Martius em 1819, entre os Uainumá (não-Tupi), no Amazonas: "Essas índias criavam um muito considerável número de galinhas, das quais nos forneceram abundante provisão » (Spix e Martius 1938, III, p. 315).

Não que os europeus demonstrassem muita aversão em consumir as espécies nativas, como bem demonstra, por exemplo, a documentação sobre a « dieta bandeirante » (Kok 2004, pp. 76-86). Mas poder degustar o familiar, mesmo nas mais remotas paragens, sugere-nos, mesmo, um conforto simbólico - «Ora, lembranças da Europa era o que mais se procurava no arsenal culinário tropical » (Pinto e Silva 2005, p. 44) -, até porque a multiplicação espetacular das galinhas domésticas nos terreiros das aldeias realizava, numa escala diminuta, um dos mais estranhos e populares desígnios das terras do Novo Mundo: berço de uma natureza exuberante, em que tudo se reproduz abundantemente, onde a fertilidade é imensa, a fartura inesgotável, as frutas são copiosas e as aves manifestam-se em profusão e diversidade (Buarque de Holanda 1959; Gerbi 1996). As galinhas, inclusive, eram maiores, mais gordas, melhores poedeiras, e muitas vezes mais saborosas do que suas congêneres européias, o que se verificava em praticamente todas as espécies de criação introduzidas com a colonização (Del Priore e Venâncio 2006, pp. 53-54).

Os povos de língua Tupi na costa parecem ter adotado estes pássaros como xerimbabos (pets) e, aparentemente, não os consideravam diferentes das outras aves que abundavam nas aldeias. No entanto, para os europeus, parecia tratar-se de artefatos da conquista, pontas de lança do processo colonizador - porque avançavam território adentro mesmo sem a presença dos colonizadores, via intercâmbios entre os grupos indígenas (Buarque de Holanda 1975, p. 199; Gilmore 1997, p. 251) ou por dispersão natural, motu proprio ${ }^{33}$ - que invadiam os universos geográficos e simbólicos das populações indígenas e, junto de ferramentas, panos, espelhos e miçangas, tornavam os índios mais parecidos com os europeus: « aliados biológicos » dos conquistadores europeus (Crosby 1972), « intermediários biológicos» (biological go-betweens) na ampla empresa colonizadora de tradução de populações, paisagens, plantas e animais até então desconhecidos (Metcalf 2005).

Tornar parecido para tornar controlável: a dispersão de animais domésticos entre as populações indígenas oferece uma imagem potente da colonização: a da domesticação da natureza feral, bruta, selvagem (Grenand 1995). A difusão dos animais domésticos nas aldeias e sua adoção pelos índios recordam o sucesso crescente do processo de transformação da selvageria em domesticidade, seja da 
natureza, seja dos índios; estes animais são o índice deste controle humano sobre a natureza - metáforas da servidão, do controle reprodutivo, da transformação dos seres vivos em riqueza material, produzida industrialmente (Benveniste 1995; Tani 1996; Fontenay 1998; Burgat 1999; Singer 2004) ${ }^{34}$. Maravilhoso que as galinhas tenham sido adotadas com tanta facilidade pelos povos indígenas e se multiplicado em tão espantosa escala: mais do que uma estratégia para abarcar o novo mundo através do discurso (Mason 1987), havia ali um esforço tangível por torná-lo, efetivamente, um espaço doméstico/domesticado. Tanto que parece ser possível concordar com Câmara Cascudo (2004, p. 249, meu grifo), inspirado:

As galinhas trouxeram um complexo antes social que alimentar no Brasil. A expansão foi extremamente rápida e alcançou vastidões inesperadas pelo interior brasileiro, sem mesmo contato direto do elemento colonizador.

Valendo anotar, apenas, duas pequenas correções: primeiro, que o complexo era social porque era alimentar, sendo este o próprio motivo do trabalho do folclorista potiguar; segundo, que o «elemento colonizador » eram as próprias galinhas. Seriam as galinhas metáforas poderosas da conquista européia, sua multiplicação espantosa espelhando o veloz crescimento demográfico e a rápida expansão territorial de portugueses e espanhóis - marcando o fim de uma era e o início de novos e difíceis tempos - como demonstra Seligmann (1987) em uma penetrante análise das complexas camadas de significados que recobriam (e recobrem) as galinhas introduzidas na história e no mito dos povos andinos? Talvez, pois as etnografias registram diferentes vinculações entre os homens brancos e a multiplicidade, a reprodutibilidade - de artefatos, de doenças, e mesmo dos próprios invasores (vários artigos em Albert e Ramos 2002).

Interessa notar que se a domesticação do continente americano passou pela difusão, ali, de espécies de plantas e animais exóticas ou exógenas, o processo inverso também se fez notar, ainda que de modo muito menos dramático; com efeito, no mesmo momento em que deixa galinhas com os índios no litoral do que será, futuramente, o sul do estado da Bahia, Cabral e seus homens recolhem e levam para a Europa numerosas aves de diversas espécies, notadamente psitacídeos, no que será, para Dean (2004, pp. 66-67) o ponto de partida do escambo colonial, mas também do processo de espoliação das matas litorâneas do Brasil e da rarefação ou extinção de inúmeras espécies nativas. Claro, estes animais levados das Américas jamais terão, na biota européia, o impacto que as espécies européias exercerão sobre os ecossistemas americanos (Crosby 2000, 2002). No entanto, a tomada destas aves pelos exploradores europeus aponta para um movimento simétrico àquele dos grupos indígenas: papagaios, araras e tucanos também foram adotados como animais de estimação e, mesmo com o uso intensivo de suas penas na indústria da moda na Europa até o início do século Xx (Schindler 2001; Françozo 2009) nunca serão objeto de criação sistemática ou em escala industrial (como são, hoje, as galinhas). Este movimento 
paralelo de adoção dos animais de estimação por europeus e ameríndios parece confirmado pela instigante sugestão de Carl Sauer (citado em Digard 1992, p. 265) de que o gosto moderno pelos animais de estimação deriva da « mania » dos animais-mascote adquiridos pelos primeiros exploradores europeus em contato com os povos indígenas americanos ${ }^{35}$.

Estas espécies de aves permanecerão exóticas, e parece haver no pensamento ocidental, ainda hoje, uma diferença entre os animais de estimação comuns (na falta de um termo melhor para, sobretudo, cães e gatos) e estas espécies consideradas exóticas (os assim chamados, pelos franceses, de NAC, sigla para Nouvel Animal de Compagnie, os « novos animais de companhia »; Talin 2000, p. 7); talvez porque, da mesma forma como se passou com as populações indígenas na costa leste da América portuguesa, estes animais não têm sua reprodutibilidade inteiramente controlada pelos humanos, permanecendo como espécimes raros, ao passo que cães e gatos são - assim como eram galinhas no Brasil de 1500-1600 - legião, pois podem ser reproduzidos de maneira fácil, mesmo descontrolada. As galinhas introduzidas nas comunidades Tupinambá - bem como em outras populações indígenas - deviam encaixar-se neste espaço intermediário: sua reprodução não era controlada (o que é o paradigma da domesticidade), mas tampouco seus filhotes precisavam ser capturados na floresta e receber cuidados atentos, maternais (o que constitui o cerne do processo de amansamento, ou pet-keeping, na Amazônia), pois estas aves se reproduziam nas aldeias e suas proximidades, e por ali mesmo cuidavam de sua sobrevivência. Há uma associação intrigante aqui: o de certas espécies animais que não são selvagens, mas tampouco são domésticos, nem domesticados. Entre a natureza e a cultura, circulam livremente nesta zona intermediária entre a alteridade e a familiaridade, neste espaço liminar no qual os homens introduzem e realizam seu tráfico. *

* Manuscrit reçu en mai 2010, accepté pour publication en septembre 2012.

\section{Notas}

Este trabalho beneficiou-se da colaboração e dos comentários, críticas e sugestões de John Manuel Monteiro, Nádia Farage, André Martini, Juliana Vergueiro Gomes Dias, Philippe Erikson, Ronaldo Rômulo de Almeida e Linda Seligmann.

1. Uma notável exceção é o livro de Melville (1994) sobre a difusão dos animais de pastoreio no México central após a conquista espanhola: um estudo de caso bastante detalhado, mas ainda assim interessado nas conseqüências ecológicas do processo, no qual os homens não são o foco principal, e as mudanças sociais são apenas esboçadas.

2. Sick (1984, p. 239) utiliza a forma Gallus gallus domesticus, para diferenciar a subespécie doméstica da espécie nativa da Ásia oriental (Gallus gallus).

3. Existe um intenso debate em torno das origens da galinha doméstica nas Américas, e alguns autores afirmam, com base, sobretudo, em evidências anatômicas, arqueológicas e lingüísticas, que " the chickens in the Americas are or were Asiatic, not Mediterranean ", posto que as variedades da 
espécie encontradas no Novo Mundo seriam mais semelhantes as suas congêneres asiáticas do que às aves européias; estas galinhas americanas teriam sido trazidas via oceano Pacífico, muito antes das viagens de descobrimento dos europeus (Carter 1998, pp. 154-158; 2004; bem como as respostas no mesmo sítio virtual). Entretanto, as evidências apresentadas por estes autores parecem pouco consistentes, em especial quando confrontadas tanto com os relatos pessoais pós-conquista quanto com os trabalhos que se valem destas fontes primárias. Tenho por fato, portanto, que as galinhas domésticas européias (da espécie Gallus domesticus ou Gallus gallus domesticus) foram, de fato, introduzidas pelos europeus nas Américas a partir de 1492; o que não indica a inexistência de outras espécies domesticadas de aves no Novo Mundo, como será visto adiante. Ver também os breves comentários em Gilmore (1997, p. 251) em torno de alguns momentos mais recuados do debate.

4. Ave ciconiforme, da família Tresquiornitídeos, também conhecida na literatura sob os nomes científicos de Ibis rubra (L.) e Guara rubra (L.) (Ribeiro B. 1988, p. 132).

5. Sabe-se que Nassau presenteou várias casas reais européias com coleções etnográficas oriundas do Brasil, muitas delas incluindo peças de arte plumária atualmente espalhadas por vários museus e coleções na Europa (Due 2002, p. 195); de acordo com Métraux (1963, p. 106), de fato, os melhores espécimes de adornos plumários dos Tupi costeiros foram coletados pelos holandeses no nordeste do Brasil. Mais antigo parece ser o adorno de penas levado por André Thevet como presente ao rei francês Henrique II, ainda no século XVI (Thevet 1944 [1556], p. 157, e as notas de Estevão Pinto nas páginas 157-158; também Hemming 1978, pp. 66-67; Due 2002, p. 194; Ribeiro B. 1987, p. 214); Métraux (1928, pp. 129-149; também 1932) discute detalhadamente os ornamentos plumários Tupinambá nos textos dos cronistas e nas coleções européias (Paris, Berlin, Copenhague, Frankfurt-aim-Main, Bâle, Florença e Bruxelas), e apresenta muitas estampas. Para breves notas sobre os seis mantos existentes, todos na Europa, ver também Grupioni (1998, pp. 251-252). A circulação, na Europa, de artefatos plumários das populações indígenas no Brasil colonial precisa ser melhor estudada, assim como as peças depositadas em diferentes acervos merecem pesquisas mais detalhadas, de modo a determinar suas origens e datas de confecção, as técnicas utilizadas e os contextos sociais e culturais desta produção.

6. Hemming (1978, p. 66) diz destas peças: " The most spectacular ornaments were broad, long cloaks entirely covered in scarlet ibis feathers ». Due (2002, p. 193) reproduz as peças plumárias da Kunstkammer Real, mas apenas a peça Hc.52 (a figura «c », no livro) traz a observação de que, possivelmente, inclui penas tingidas de galinha; este manto é diferente da peça trazida para o Brasil na ocasião da Mostra do Redescobrimento (reproduzida numa belíssima fotografia em Aguilar 2000, p. 119), também parte da coleção da Kunstkammer real, com o registro H.5931. O catálogo oficial dos objetos etnográficos do museu dinamarquês reproduz belamente todas as peças; no entanto, as descrições não mencionam penas de galinha, limitando-se a " feathers are of the parrot, toucan, red ibis, and other birds » (Dam-Mikkelsen e Lundbæk 1980, pp. 27-30, meu grifo). Métraux (1932, p. 8) diz que o manto de Copenhague se distingue do exemplar por ele analisado no Museu do Trocadéro " par une plus grande variété dans le choix des plumes: à celles de guará ont été ajoutées quelques plumes noires »; não menciona, contudo, as penas de galinhas domésticas.

7. Quanto ao « contexto colonial » da produção destes adornos, deve-se registrar que um dos mantos Tupinambá guardados em coleções européias - o do Museu do Homem, em Paris - traz, em sua extremidade superior, uma tira de miçangas azuis e brancas de origem européia (Métraux 1932, p. 4; Grupioni 1998, p. 251). O uso de materiais exóticos para a confecção destes importantes artefatos Tupinambá parece não ter se restringido às penas de galinha.

8. Evitei os termos «doméstico », « domesticado », « semidomesticado » ou « criado », pois o estatuto das galinhas araucanas entre as populações ameríndias parece não estar resolvido. Sick (1984, p. 85), por exemplo, afirma que a única ave domesticada « no sentido rigoroso da palavra » (?), na América do Sul, é o pato-do-mato (Cairina moschata), o que confirma a informação de Gilmore (1997, p. 218; também Digard 1990; Donkin 1989, pp. 18-22, em seu exaustivo estudo, menciona apenas o pato-do-mato, embora sugira que o peru, Melleagris gallopavo, possa ter sido difundido no noroeste da América do Sul via istmo do Panamá). Entretanto, este último autor fornece uma listagem de espécies animais « semidomesticadas », que inclui pelo menos oito aves, e entre estas vários cracídeos; não cita, 
entretanto, a galinha araucana, que só aparece em seu texto mais adiante, quando discute as galinhas domésticas européias (Gilmore 1997, p. 251). Sick (1984, pp. 239-240), novamente, informa que as galinhas araucanas eram criadas pelos índios Araucano, no Chile, e Garavaglia (1999, p. 34) refere-se às galinhas araucanas (araucanian hen) apenas como local fowl, admitindo a possibilidade desta espécie ter confundido observadores europeus. Embora a questão, pelo menos nas terras baixas sul-americanas, pareça ser resolvida pela oposição entre domesticação (domestication) e « amansamento » (apprivoisement) - no sentido de uma relação entre controle reprodutivo de uma espécie versus familiarização de indivíduos de certas espécies -, o estatuto das duas aves parece demandar ainda mais estudos (ver abaixo). Sobre o controvertido debate em torno da « domesticidade » nas terras baixas sul-americanas remeto a Erikson (1987, 1988, 1998), Digard (1992, 1994) e Descola $(1994,1998,2002)$.

9. Sabe-se que os artistas holandeses no Nordeste retrataram vários animais não-nativos do Brasil, mas então já aclimatados em terras americanas (bois, cavalos, cabras). Isso pode sugerir um interesse desses artistas na própria adaptação desses seres - aos quais já estavam acostumados em latitudes setentrionais - às condições climáticas - mas também econômicas e sociais - dos trópicos. A questão das representações de animais do Brasil pelos artistas holandeses é complexa, e demanda um estudo mais aprofundado.

10. Digard (1992, p. 261) afirma que as galinhas-d'Angola são de criação e controle mais difícil que as galinhas comuns, e que em alguns lugares das Américas elas escaparam dos criatórios e tornaram ao estado selvagem, multiplicando-se desordenadamente e convertendo-se em um "véritable fléau " na ilha de Hispaniola, por exemplo.

11. Sobre a « inautenticidade » das penas de galinha em uso por grupos indígenas, veja-se, por exemplo, o caso Pataxó no sul da Bahia, descrito por Grünewald (2001, p. 166), que afirma que os índios, para não dizerem aos turistas que seu artesanato é produzido com penas de galinha coloridas artificialmente, dizem que são penas de xukakai (galinha), utilizando uma palavra na língua Pataxó, pretendendo, assim, conferir autenticidade ou « indianidade » às peças.

12. Sabemos que a ornamentação corporal é de importância crucial para as populações indígenas nas terras baixas sul-americanas, e que ela tem complexas interações com a arte, a opinião pública e a mídia nas sociedades contemporâneas; sobre esta questão ver Conklin (1997) e Vilaça (2000).

13. Como são até hoje, a julgar pelo enorme volume do tráfico de animais silvestres ao redor do planeta; as aves exóticas respondem por boa parte deste comércio ilícito, cruel e danoso.

14. Donkin (1989, p. 83) está certo de que as gallinas de Acuña eram mesmo de origem européia. A origem peruana das aves, apontada pelo padre, pode sugerir a existência de outras rotas de difusão destas aves - bem como de outros animais e artefatos - e redes de contato e intercâmbio entre os Andes e a Amazônia, que merecem melhor investigação.

15. No que são repetidos também por Thevet, que anota arignane; entretanto, aparentemente, ele se refere aos ovos de galinha.

16. Conforme Wagley (1988, p. 87), os Tapirapé denominam as galinhas wuram champokaiya, « ave que grita ». Que se trata de cognato de gûirá-sapukaîa parece evidente.

17. Os Karitiana, povo de língua Tupi-Arikém em Rondônia, com quem trabalho, falam " garinha », o que sugere ainda maior aproximação com a sugestão de Sérgio Buarque.

18. Mais uma vez, recorro ao material Karitiana, que parecem perceber esta multiplicação profícua das galinhas como seu atributo mais significativo: eles denominam as galinhas domésticas de opok ako, que se traduz literalmente por «os muitos do branco », ou seja, aquilo que os brancos possuem em grande quantidade. A figura do excesso parece ser o denominador comum na percepção destas aves pelos grupos indígenas de língua Tupi: Lima (2005, p. 144), por exemplo, registra que os Yudjá dizem que as galinhas copulam o tempo todo; os mesmos comportamentos excessivos das aves podem ter sido notados pelos Tupinambá, a crer nas suas denominações como « aves que gritam » ou « que correm (não voam) ».

19. Um tanto contraditória é a informação de Jensen (1985, pp. 50-51) a respeito dos Wayampi, que informa que, embora consideradas nima (animal doméstico), as galinhas e seus ovos são criadas 
especificamente para consumo alimentício por este grupo Tupi. Segundo o mesmo autor outras aves domesticadas não são comidas (ibid., p. 51). Nordenskiöld (1922, pp. 10-11) afirmou que os grupos indígenas na América do Sul manteriam galinhas, como outros pets, sobretudo pela companhia, e não por sua carne e ovos, que não eram consumidos; informação controversa, a julgar pelos incontáveis exemplos de seu consumo, por vezes mesmo preferencial (Coffaci de Lima 2000, p. 66; ver nota seguinte).

20. Interessante notar que Câmara Cascudo (2004, pp. 250-251) aponta que as galinhas não eram, mesmo em Portugal, aves de consumo corriqueiro, criadas muito mais para a venda de ovos e frangos do que para serem comidas pelos criadores. Koster (1942 [1818]), viajando pelo sertão nordestino do Brasil em 1811, deixou-nos uma deliciosa passagem, que parece ilustrar uma forma de relação social tecida entre mulheres e suas aves domésticas: " As mulheres, como é natural, possuíam a direção da capœira e, depois de muito regatear findavam dizendo que todas [as galinhas] eram suas favoritas, para si e seus filhos, não consentindo jamais que uma só fosse morta ». Ademais, no Brasil, galinhas e frangos domésticos eram, sobretudo, alimentos reservados para festas e para os enfermos (Pinto e Silva 2005 , pp. 42-43; Meneses 2000, p. 123). Simoons (1966) sustenta que há um surpreendente pequeno interesse no consumo de galinhas e seus ovos em todo o mundo. Note-se que o problema colocado pelo ovo - «filosófico », entre os Araweté de Viveiros de Castro, "venenoso », entre os Tupinambá de Léry - não parece ser extensível a outros grupos Tupi: entre os Suruí (Tupi-Mondé) no sudoeste da Amazônia brasileira, os ovos de galinha são « cobiçadíssimos », e estavam entre os principais itens furtados aos colonos vizinhos ao seu território (Mindlin 1985, pp. 55, 66); da mesma forma, os Guajá (Tupi-Guarani) são relutantes em comer as galinhas que criam, mas consomem seus ovos (Cormier 2003, p. 122). De sua parte, os Karitiana, Tupi-Arikém em Rondônia, comem ovos apenas raramente, porque seu consumo leva as mulheres a engravidarem repetidamente, risco que existe até mesmo no simples pisar em cascas de ovos (Vander Velden 2010).

21. Kracke (1978, p. 11) registrou que os Tupi-Kawahib manifestavam desconforto em consumir a carne de galinhas e porcos; podiam abater galinhas para alimentar crianças resistentes a outros alimentos, mas o autor reafirma a aversão, ao apontar que esta era uma atitude " indulgente » $(\mathrm{ibid}$., pp. 27, 144).

22. Atente-se que estas sugestões foram retiradas de trabalhos sobre dois grupos (os Huaulu e os Nuaulu) que vivem na ilha de Seram, na Indonésia oriental. Não obstante, penso que as pesquisas sobre a domesticação animal e a introdução de espécies exógenas só têm a ganhar com uma perspectiva comparativa bastante ampla (Simoons e Baldwin 1982; Digard 1988; Dalla Bernardina 1991).

23. Ver nota 8 .

24. O que, de resto, acontece mesmo nos sistemas industriais contemporâneos, nos quais as galinhas, mais do que qualquer outro animal de criação (com exceção, possivelmente, dos peixes; ver Martini 2008), são ícones da multiplicidade exagerada e impressionante, e da produção em massa, de centenas de milhares de aves em uma única granja: « nossa cultura nos ensina a não ver galinhas [...] como indivíduos distintos » (Regan 2006, p. 123, grifo no original; também pp. 110-116; ver também Singer 2004, pp. 107-135). Galinhas são, numericamente, o maior grupo de animais domésticos no planeta (Shanklin 1985, p. 379); sobre o ícone da multiplicação, ver o impressionante conto de Highsmith (2005), «O dia do acerto de contas ».

25. Os Karitiana, como outros grupos indígenas, também parecem dizer que comem galinhas, embora não as comam: jamais presenciei o abate de uma galinha, exceto uma vez, e a ave foi perseguida e morta com arco e flecha (arma que, note-se, quase não é mais empregada na caça ordinária). Ademais, os Karitiana comem, sim, galinhas: as compradas em mercados na cidade, ou aquelas que roubam aos vizinhos (acusações de que fulano está " roubando » ou " comendo » as galinhas de outrem são extremamente comuns). Galinhas não recebem nomes, nem são objeto de cuidados especiais (embora alguns pintinhos possam sê-lo). E são signo de multiplicidade: ver, a respeito, as notas 18 e 20.

26. Conforme o testemunho de Léry, as penas brancas eram tingidas em uma decocção de pau-brasil. Métraux (1963, p. 102) descreve o processo denominado tapiragem, por meio do qual os 
Tupinambá alteravam as cores das penas das aves esfregando nestas o sangue de uma espécie de rã; nada diz o autor, entretanto, sobre se este processo era aplicado nas galinhas introduzidas.

27. Observe-se o comentário de Viveiros de Castro (1986, p. 476) sobre a predileção e a onipresença da cor vermelha entre os Araweté, povo de língua Tupi-Guarani.

28. D’Evreux (2002 [1615], pp. 199-200) maravilhou-se com esta ave no Maranhão, e dá uma descrição detalhada da coloração de sua plumagem.

29. Métraux (1928, pp. 146-147) afirma que, do ponto de vista iconográfico, as melhores figurações dos mantos Tupinambá são esta imagem da edição alemã de Léry por de Bry - reproduzida por Métraux na página 147 - e uma pequenina estampa de Hans Staden, que Métraux reproduz na página 135 de seu livro.

30. Sobre as penas de aves como riqueza e bens simbólicos de alto valor, e sobre os xamãs como aves, ver os comentários de Giannini (1991, pp. 96-99) sobre os Kayapó-Xikrin.

31. Claude d'Abbeville pode ter visto estruturas erguidas para abrigar as galinhas durante a noite e protegê-las de ataques de certos animais noturnos - como morcegos e felinos -, comuns, por exemplo, nas casas da aldeia Karitiana atual, e denominadas « galinheiros ». Se a prática de levantar abrigos para os animais na aldeia é anterior a conquista é difícil saber: Métraux (1963, p. 692), referindo-se aos grupos Tupi no alto Solimões (Omágua e Cocama), fala em galinhas mantidas em abrigos especiais, à salvo de morcegos vampiros, mas apenas « in recent times ».

32. Ferdinand Denis, em nota ao texto de Yves D'Evreux, afirma que os guarás eram raros mesmo no século XVII, e que os Tupinambá organizavam verdadeiras expedições para buscar suas penas (Denis 2002 [1864], p. 413).

33. « Tão rápida [a difusão das galinhas pelo Novo Mundo], na verdade, que, em alguns casos, iam encontrá-las [as galinhas] os conquistadores em terras nunca dantes visitadas por europeu » (Buarque de Holanda 1975, p. 199).

34. Note-se a diferença fundamental entre o animal doméstico/domesticado e o animal amansado/familiarizado: enquanto o primeiro descrito como "servo » (Tani 1996) nas culturas indo-européias - uma relação definida em função do trabalho e do controle rigoroso da reprodução e da hierarquia dos seres e indivíduos -, os segundos aproximam-se da posição do « cativo » (de guerra), que remete não apenas a sua origem estrangeira como ao estatuto ambíguo ou anômalo que parece experimentar entre seus captores (Menget 1988; Santos-Granero 2009).

35. O que condiz com a sugestão de Thomas (2001, pp. 119-144) de que foi justamente nos séculos XVI e XVII - período dos grandes descobrimentos - que os mascotes animais firmaram-se nas residências, sentimentos e gostos das populações européias, sobretudo na Grã-Bretanha.

\section{REFERÊNCIAS CITADAS}

Acuña Pe. Cristóbal de

1994 Novo descobrimento do rio Amazonas, Consejería de Educación de Embajada de Espana em Brasil/Oltaver, Montevidéu [1639].

Aguilar Nelson (ed.)

2000 Artes indígenas. Catálogo da Mostra do Redescobrimento, Fundação Bienal de SP/MRE/MinC/Brasil Artes Visuais, São Paulo.

Albert Bruce e Alcida Rita Ramos (eds)

2002 Pacificando o branco: cosmologias do contato no Norte-Amazônico, Imprensa Oficial/Edunesp/IRD, São Paulo. 
BALÉE William

1994 Footprints of the forest: Ka'apor ethnobotany. The historical ecology of plant utilization by na Amazonian people, Columbia University Press, New York.

Barbosa Wallace de Deus

1999 «O artesanato indígena e os "novos índios" do Nordeste », Revista do Patrimônio Histórico e Artístico Nacional, 28, pp. 198-215.

BARLÉU Gaspar

1974 História dos feitos recentemente praticados durante oito anos no Brasil, Itatiaia/Edusp, Belo Horizonte/SãoPaulo [1647].

BAsso Ellen

1973 The Kalapalo indians of Central Brazil, Holt, Rinehart \& Winston, New York.

BENVENISTE Émile

$1995 O$ vocabulário das instituições indo-européias. Vol. I. Economia, parentesco, sociedade, Editora da Unicamp, Campinas.

BRANDÃo Ambrósio

1966 Diálogos das Grandezas do Brasil, Imprensa Universitária da UFPE, Recife [1618].

Buarque de Holanda Sérgio

1959 Visão do Paraíso: os motivos edênicos no descobrimento e colonização do Brasil, Editora José Olympio, Rio de Janeiro.

1975 Caminhos e fronteiras, Livraria José Olympio Editora, Rio de Janeiro.

BURGAT Florence

1999 «La logique de la légitimation de la violence: animalité vs humanité », in Françoise Héritier (ed.), De la violence. II, Éditions Odile Jacob, Paris, pp. 45-62.

Cabeza de Vaca Álvar Nuñez

1999 Naufrágios e comentários, L\&PM, Porto Alegre [1540-1545].

CÂmara CAScudo Luís da (S/d)

2004 História da alimentação no Brasil, Editora Global, São Paulo.

Caminha Pero Vaz de

1999 «Carta a El-Rei D. Manuel I », in Paulo Roberto Pereira (ed.), Os três únicos testemunhos do descobrimento do Brasil, Lacerda Editores, Rio de Janeiro, pp. 31-66 [1500].

CARDIM Fernão

1980 Tratados da terra e gente do Brasil, Itatiaia/Edusp, Belo Horizonte/São Paulo [1625].

Carneiro da Cunha Manuela e Eduardo Viveiros de Castro

1985 «Vingança e temporalidade: os Tupinambá », Journal de la Société des Américanistes, 71, pp. 191-217.

CARTER George

1998 "The chicken in America », in David Gilmore e Linda McElroy (eds), Across before Columbus?, NEARA Publications, Edgecomb. 
2004 « Reply: which came first? The chicken or the Spanish?» [www.hallofmaat.com/read.php?1 (acesso em 05/12/2005)].

\section{CATHarino José Martins}

1995 Trabalho índio em Terras da Vera ou Santa Cruz e do Brasil: tentativa de resgate ergonológico, Editora Salamandra, Rio de Janeiro.

COFFACI DE Lima Edilene

2000 Com os olhos da serpente: homens, animais e espíritos nas concepções Katukina sobre a natureza, tese de doutorado, USP, São Paulo.

ConKLIN Beth

1997 «Body paint, feathers, and VCRs: aesthetics and authenticity in Amazonian activism », American Ethnologist, 24 (4), pp. 711-737.

CORMIER Loretta

2003 Kinship with monkeys: the Guajá foragers of eastern Amazonia, Columbia University Press, New York.

Crosby Alfred

1972 The Columbian exchange: biological and cultural consequences of 1492, Greenwood Press, Westport.

1991 "Metamorphosis of the Americas », in Herman Viola e Carolyn Margolis (eds), Seeds of change: a quincentennial commemoration, Smithsonian Institution Press, Washington, pp. 70-89.

2000 «Ecological imperialism: the overseas migration of western Europeans as a biological phenomenon », in Peter Mancall e James Merrell (eds), American encounters: natives and newcomers from european contact to Indian removal, 1500-1850, Routledge, London/New York, pp. 55-67.

2002 Imperialismo ecológico. A expansão biológica da Europa: 900-1900, Companhia das Letras, São Paulo.

CuÉLlar Erika e Andrew Noss (eds)

2003 Mamíferos del Chaco y de la Chiquitania de Santa Cruz, Bolivia, FAN/WVC, Santa Cruz de la Sierra.

D’Abbeville Pe. Claude

2002 História da missão dos padres capuchinhos na Ilha do Maranhão e suas circunvizinhanças, Editora Siciliano, São Paulo [1614].

Dalby Andrew

2003 Food in the Ancient World from A-Z, Routledge, London.

Dalla Bernardina Sergio

1991 «Une personne pas tout à fait comme les autres: l'animal et son statut », L'Homme, XXXI (120), pp. 33-50.

DAM-MikKelSEn Bente e Torben LundBæK (eds)

1980 Etnografiske genstande i Det kongelige danske Kunstkammer 1650-1800, Nationalmuseet, Kbenhavn.

DEAN Warren

2004 A ferro e fogo: a história e a devastação da Mata Atlântica brasileira, Companhia das Letras, São Paulo [1996]. 
Del Priore Mary e Renato Venâncio

2006 Uma história da vida rural no Brasil, Ediouro, Rio de Janeiro.

DenIs Ferdinand

1980 Brasil, Itatiaia/Edusp, Belo Horizonte/São Paulo [1838].

2002 «Notas críticas e históricas sobre a viagem do Padre Yves De Evreux por Mr. Ferdinand Denis ", Publicado como apêndice em Yves D'Evreux, Viagem ao norte do Brasil feita nos anos de 1613 e 1614, Editora Siciliano, São Paulo [1864].

Descola Philippe

1994 «Pourquoi les Indiens d'Amazonie n'ont-ils pas domestiqué le pécari? Généalogie des objets et anthropologie de l'objectivation », in Bruno Latour e Pierre Lemmonier (eds), De la préhistoire aux missiles balistiques. L'intelligence sociale des techniques, La Découverte, Paris, pp. 329-344.

1998 «Estrutura ou sentimento: a relação com o animal na Amazônia », Mana. Estudos de Antropologia Social, 4 (1), pp. 23-45.

1999 «Des proies bienveillantes: le traitement du gibier dans la chasse amazonienne », in Françoise Héritier (ed.), De la violence. II, Éditions Odile Jacob, Paris, pp. 19-44.

2002 "Genealogia dos objetos e antropologia da objetivação », Horizontes Antropológicos, 8 (18), pp. 93-112.

D'Evreux Yves

2002 Viagem ao norte do Brasil feita nos anos de 1613 a 1614, Editora Siciliano, São Paulo [1615].

DiAMOND Jared

1999 Guns, germs, and steel: the fates of human societies, W. W. Norton \& Company, New York.

2005 Colapso: como as sociedades escolhem o fracasso ou o sucesso, Record, Rio de Janeiro.

Digard Jean-Pierre

1988 « Jalons pour une anthropologie de la domestication animale », L'Homme, 28 (108), pp. 27-58.

1990 "Compte rendu », L'Homme, 30 (116), pp. 187-188.

1992 «Un aspect méconnu de l'histoire de l'Amérique: la domestication des animaux », L'Homme, 32 (122-124), pp. 253-270.

1994 « Naturaleza y antropologia: la domesticación », in Carmen Bernand (ed.), Descubrimiento, conquista y colonización de América a quinientos años, Fondo de Cultura Economica, Consejo Nacional para la Cultura y las Artes, México, pp. 127-147.

DonkIn Robin Arthur

1989 The Muscovy Duck, Cairina moschata domestica. Origins, dispersal, and associated aspects of the geography of domestication, A. A. Balkema, Rotterdam/Brookfield.

Dorst Jean

1973

Antes que a natureza morra: por uma ecologia política, Edgard Blücher, São Paulo. 
Due Berete 2002

«Artefatos brasileiros no Kunstkammer Real», in Barbara Berlowicz, Berete Due, Peter Pentz e Espen Wæhle (eds), Albert Eckhout volta ao Brasil 1644-2002, Nationalmuseet, Copenhagen, pp. 187-195.

ELLEN Roy

1999

« Categories of animality and canine abuse: exploring contradictions in Nuaulu social relationships with dogs », Anthropos, 94, pp. 57-68.

\section{ERIKSON Philippe}

1987 «De l'apprivoisement à l'approvisionnement: chasse, alliance et familiarisation en Amazonie amérindienne », Techniques et Cultures, 9, pp. 105-140.

1988 "Apprivoisement et habitat chez les Amérindiens Matis (langue pano, Amazonas, Brésil) ». Anthropozoologica, 9, pp. 25-35.

1998 «Du pécari au manioc ou du riz sans porc? Réflexions sur l'introduction de la riziculture et de l'élevage chez les Chacobo (Amazonie bolivienne) », Techniques et Cultures, 31-32, pp. 363-378.

2000 " The social significance of pet-keeping among the Amazonian Indians », in Anthony Podberscek, Elizabeth Paul e James Serpell (eds), Companion animals and us: exploring the relationships between people and pets, Cambridge University Press, Cambridge, pp. 7-26.

FAusto Carlos

1992 «Fragmentos de história e cultura Tupinambá: da etnologia como instrumento de conhecimento etno-histórico », in Manuela Carneiro da Cunha (ed.), História dos Índios no Brasil, Fapesp, SMC, Companhia das Letras, São Paulo, pp. 381-396.

2000 " Of enemies and pets: warfare and shamanism in Amazônia », American Ethnologist, 26 (4), pp. 933-956.

2001 Inimigos fiéis: história, guerra e xamanismo na Amazônia, Edusp, São Paulo.

FERNANDES Florestan

1970 A função social da guerra na sociedade Tupinambá, Pioneira/Edusp, São Paulo.

1975 A investigação etnológicano Brasile outros ensaios, Editora Vozes, Petrópolis.

FernANDES João Azevedo

2003 De cunhã a mameluca: a mulher Tupinambá e o nascimento do Brasil, Editora Universitária da UFPB, João Pessoa.

FonTENay Elisabeth de

1998 Le silence des bêtes: la philosophie à l'épreuve de l'animalité, Fayard, Paris.

FrançOzo Mariana

2009 De Olinda a Olanda: Johan Maurits van Nassau e a circulação de objetos e saberes no Atlântico holandês (século XVII), tese de doutorado, Unicamp, Campinas.

Furst Peter

1991 "Crowns of power: bird and feather symbolism in Amazonian shamanism », in Ruben Reina e Kenneth Kensinger (eds), The gift of birds: 
featherwork of native South American peoples, The University Museum of Archaeology and Anthropology, University of Pennsylvania, Philadelphia, pp. 92-109.

Gandavo Pero de Magalhães.

1980 História da Província de Santa Cruz, Itatiaia/Edusp, Belo Horizonte/São Paulo [1576].

Garavaglia Juan Carlos

1999 "The crisis and transformations of invaded societies: the La Plata basin (1535-1650) », in Frank Salomon e Stuart Schwartz (eds), The Cambridge history of the Native Peoples of the Americas. Vol. III. South America (part. 2), Cambridge University Press, Cambridge, pp. 1-58.

GERBi Antonello

1996 O Novo Mundo: história de uma polêmica. 1750-1900, Companhia das Letras, São Paulo.

GiANNINI Isabelle Vidal

$1991 \quad A$ ave resgatada: " $A$ impossibilidade da leveza do ser », dissertação de mestrado, USP, São Paulo.

GiLmore Raymond

1997 «Fauna e etnozoologia da América do Sul tropical », in Berta Ribeiro (ed.), Suma etnológica Brasileira. Vol. I. Etnobiologia, Editora Universitária da UFPA, Belém, pp. 217-277.

GRENAND Françoise

1995 «Nommer la nature dans un contexte prélinnéen: les Européens face aux Tupi du $\mathrm{XVI}^{\mathrm{e}}$ à la première moitié du XVII ${ }^{\mathrm{e}}$ siècle », Amérindia, 19-20, pp. $15-28$.

GRÜMBERG Georg

2004 Os Kaiabi do Brasil central: história e etnografia, Instituto Socioambiental, São Paulo.

GRÜNEWALD Rodrigo

2001 Os índios do descobrimento: tradição e turismo, Contra Capa, Rio de Janeiro.

GRUPIONI Luís Donisete B.

1998 «Inventário dos artefatos e obras da exposição "Índios no Brasil: alteridade, diversidade e diálogo cultural" ", in Luís D. Grupioni (ed.), Índios no Brasil, Editora Global/MEC, São Paulo/Brasília, pp. 233-273.

HeMming John

1978 Red gold: the conquest of the Brazilian Indians, Harvard University Press, Cambridge.

Highsmith Patricia

2005 O livro das feras, L\&PM, Porto Alegre.

JENSEN Allen

1985 Sistemas indígenas de classificação de aves: aspectos comparativos, ecológicos e evolutivos, tese de doutorado, Unicamp, Campinas. 
KENSINGER Kenneth

1995 How real people ought to live: the Cashinahua of Eastern Peru, Waveland Press, Prospect Heights.

KIPLE Kenneth F. e Kriemhild C. Ornelas

2000 Cambridge world history of food. Vol. I, Cambridge University Press, Cambridge.

KoK Glória

2004 O sertão itinerante: expedições da Capitania de São Paulo no século XVIII, Hucitec, Fapesp, São Paulo.

Koster Henry

1942 Viagens ao Nordeste do Brasil, Cia. Editora Nacional, São Paulo [1818].

KRACKE Waud

1978 Force and persuasion: leadership in an Amazonian society, University of Chicago Press, Chicago.

LÉRY Jean de

1980 Viagem à Terra do Brasil, Itatiaia/Edusp, Belo Horizonte/São Paulo [1578].

LÉVI-STRAuss Claude

1963 "The Tupi-Cawahib », in Julian Steward (ed.), Handbook of South American Indians. Vol. 3. The tropical forest tribes, Cooper Square Publishers, New York, pp. 299-305.

1989 O pensamento selvagem, Editora Papirus, Campinas.

Lima Tânia Stolze

2005 Um peixe olhou para mim: o povo Yudjá e a perspectiva, Edunesp, ISA/NuTI, São Paulo/Rio de Janeiro.

Marchant Alexander

1943 Do escambo à escravidão: as relações econômicas de portugueses e índios na colonização do Brasil, 1500-1580, Companhia Editora Nacional, São Paulo.

MarTini André

2008 Filhos do homem: a introdução da piscicultura entre populações indígenas no povoado de Iauaretê, rio Uaupés, dissertação de mestrado, Unicamp, Campinas.

Mason Peter

1987 «Notes on cormorant fishing: Europe and its others », IberoAmerikanisches Archiv, N.F., Jg 13, H. 2, pp. 147-174.

Melville Elinor

1994 A plague of sheep: environmental consequences of the conquest of Mexico, Cambridge University Press, Cambridge.

MeNeSES José Newton

$2000 \quad O$ continente rústico: abastecimento alimentar nas Minas Gerais setecentistas, Maria Fumaça, Diamantina.

Menget Patrick

1988 « Note sur l'adoption chez les Txicáo du Brésil Central », Anthropologie et Societés, 12 (2), pp. 63-72. 
Metcalf Alida

2005 Go-betweens and the colonization of Brazil: 1500-1600, University of Texas Press, Austin.

MÉTRaux Alfred

1928 La civilisation matérielle des tribus tupi-guarani, Librairie orientaliste Paul Geuthner, Paris.

1932 «À propos de deux objets Tupinamba du musée d'Ethnographie du Trocadéro », Bulletin du Musée d'Etnographie du Trocadéro, 2, pp. 3-18.

1963 "The Tupinambá » e « Tribes of the middle and upper Amazon river », in Julian Steward (ed.), Handbook of South American Indians. Vol. 3. The tropical forest tribes, Cooper Square Publishers, New York, pp. 95-133 e 687-712.

1979 A religião dos Tupinambás e suas relações com a das demais tribos Tupi-Guaranis, Editora Nacional, Edusp, São Paulo.

Miceli Paulo

$1998 \quad O$ ponto onde estamos: viagens e viajantes na história da expansão e da conquista (Portugal, séculos XV e XVI), Editora da Unicamp, Campinas.

MindLin Betty

1985 Nós Paiter. Os Suruí de Rondônia, Editora Vozes, Petrópolis.

Nimuendaju Curt

1963 «Tribes of the lower and middle Xingú river »e « The Cayabi, Tapanyuna, and Apiaca ", in Julian Steward (ed.), Handbook of South American Indians. Vol. 3. The tropical forest tribes, Cooper Square Publishers, New York, pp. 213-243 e 307-320.

NóBrega Pe. Manuel da

2006 «Informação das partes do Brasil », in Sheila Hue (ed.), Primeiras cartas do Brasil (1551-1555), Jorge Zahar Editor, Rio de Janeiro, pp. 31-41 [1549].

Nomura Hitoshi

1996 Avifauna no folclore, Fundação Vingt-Um Rosado, ETFRN-UNED, Secretaria de Educação, Cultura e Desporto do RN, col. « Mossoroense » 903, Mossoró.

NORDENSKIÖLD Erland

1922 Deductions suggested by the geographical distribution of some post-columbian words used by the Indians of South America, Elanders Boktryckeri Aktiebolag, col. « Comparative Ethnographical Studies » 5, Göteborg.

Olmos Fábio e Robson Silva e Silva

2003 Guará: ambiente, flora e fauna dos manguezais de Santos-Cubatão, Empresa das Artes, São Paulo.

PACHeCo DE Oliveira João (ed.)

1999 A viagem da volta: etnicidade, política e reelaboração cultural no Nordeste indigena, Contra Capa, Rio de Janeiro.

Perrone-Moisés Leyla

1992 Vinte luas. Viagem de Paulmier de Gonneville ao Brasil: 1503-1505, Companhia das Letras, São Paulo. 
Petersen Karen e Anne Sommer-Larsen

1979-1980 «Techniques applied to some feather garments from the Tupinamba Indians, Brazil », Folk, 21-22, pp. 263-270.

Pinto e Silva Paula

2005 Farinha, feijão e carne-seca: um tripé culinário no Brasil colonial, Editora SENAC, São Paulo.

QueIXaLós Francisco

1993 "Les mythes et les mots de l'identité sikuani », in Aurore Monod Becquelin e Antoinette Molinié (eds), Mémoire de la tradition, Société d'Ethnologie, Nanterre.

REgAN Tom

2006 Jaulas vazias: encarando o desafio dos direitos animais, Lugano, São Paulo.

ReINA Ruben e Kenneth Kensinger (eds)

1991 The gift of birds: featherwork of native South American peoples, University of Pennsylvania, The University Museum of Archaeology and Anthropology, Philadelphia.

Ribeiro Berta (ed.)

1987 Suma etnológica brasileira. Vol. III. Arte índia, Editora Vozes, Finep, Petrópolis.

1988 Dicionário do artesanato indígena, Itatiaia/Edusp, Belo Horizonte/ São Paulo.

RIBEIRo Darcy

1996 Diários índios: os Urubus-Kaapor, Companhia das Letras, São Paulo.

Ribeiro Darcy e Carlos Araújo Moreira Neto (eds)

1992 A fundação do Brasil: testemunhos (1500-1700), Editora Vozes, Petrópolis.

SAIGNES Thierry

1999 "The colonial condition in the Quechua-Aymara heartland (1570-1780) », in Frank Salomon e Stuart Schwartz (eds), The Cambridge History of the Native Peoples of the Americas. Vol. III. South America (part. 2), Cambridge University Press, Cambridge, pp. 59-137.

SALVADOR Frei Vicente de

1954 História do Brasil, Melhoramentos, São Paulo [1590-1627].

SAMPaIo Teodoro

1987 O Tupi na geografia nacional, Editora Nacional/INL, São Paulo/Brasília.

SANTOS-Granero Fernando

2009 Vital enemies: slavery, predation, and the Amerindian political economy of life, University of Texas Press, Austin.

SCHINDLER Helmut

2001 «Plumas como enfeites da moda », História, Ciências, Saúde: Manguinhos, VIII (suplemento), pp. 1089-1108.

SCHRÖDER Peter

2003 Economia indígena: situação atual e problemas relacionados a projetos indígenas de comercialização na Amazônia legal, Editora Universitária da UFPE, Recife. 
SCHWARTz Stuart

1978 «Indian labor and New World plantations: European demands and Indian responses in Northeastern Brazil », The American History Review, 83 (1), pp. 43-79.

Seligmann Linda

1987 "The chicken in Andean history and myth: the Quechua concept of Wallpa », Ethnohistory, 34 (2), pp. 139-170.

SERPELL James

1996 In the company of animals: a study of human-animal relationships, Cambridge University Press, Cambridge.

SHANKLin Eugenia

1985 «Sustenance and symbol: anthropological studies of domesticated animals », Annual Review of Anthropology, 14, pp. 375-403.

Sick Helmut

1984 Ornitologia brasileira: uma introdução. Vol. 1, Editora da UnB, Brasília.

Simoons Frederick

1966 Eat not this flesh: food avoidance in the Old World, University of Wisconsin Press, Madison.

1974 «Contemporary research themes in the cultural geography of domesticated animals », Geographical Review, 64 (4), pp. 557-576.

Simoons Frederick e James BALDwin

1982 «Breast-feeding of animal by women: its socio-cultural context and geographic occurrence », Anthropos, 77, pp. 421-448.

SINGER Peter

2004 Libertação animal, Lugano, Porto Alegre/São Paulo.

SMIth Paige e Charles DANIEL

1975 The chicken book, University of Georgia Press, Athens.

SOARES DE SOUSA Gabriel

1987 Tratado descritivo do Brasil em 1587, Editora Nacional/INL, col. « Brasiliana » 177, São Paulo/Brasília [1587].

SPIX Johann B. von e Carl F. Ph. Von Martius

1938 Viagem pelo Brasil (1817-1820). Vol. III, Imprensa Nacional, Rio de Janeiro.

STADEN Hans

1999 Hans Staden: primeiros registros escritos e ilustrados sobre o Brasil e seus habitantes, Editora Terceiro Nome, São Paulo [1557].

TALIN Christian

2000 Anthropologie de l'animal de compagnie: l'animal, autre figure de l'altérité, L'Atelier de l'Archer, Paris. 
TANI Yutaka

1996 "Domestic animal as serf: ideologies of nature in the Mediterranean and the Middle East », in Roy Ellen e Katsuyoshi Fukui (eds), Redefining nature: ecology, culture, and domestication, Berg, Oxford, pp. 387-415.

TAYLOR Anne Christine

2001 «Wives, pets, and affines: marriage among the Jivaro », in Laura Rival e Neil Whitehead (eds), Beyond the visible and the material: the amerindianization of society in the work of Peter Rivière, Oxford University Press, Oxford, pp. 45-56.

TeIXeIRa Dante Martins

1998 Brasil Holandês. Vol. I. Coleção Niedenthal e vol. II Animaux et oiseaux, Editora Index, Rio de Janeiro (3 volumes).

$2004 \quad$ « mito da natureza intocada: a história natural no Brasil holandês (1624-1654) e sua contribuição para o conhecimento da história recente da fauna do Novo Mundo », in Vera Lúcia Tostes, Sarah Benchetrit e Aline Magalhães (eds), A presença holandesa no Brasil: memória e imaginário, Museu Histórico Nacional, Rio de Janeiro, pp. 271-306.

THEvet André

1944 Singularidades da França Antártica, a que outros chamam de América, Companhia Editora Nacional, São Paulo [1556].

ThOMAs Keith

$2001 \quad O$ homem e o mundo natural: mudanças de atitudes em relação às plantas $e$ aos animais (1500-1800), Companhia das Letras, São Paulo.

VALERI Valerio

1992 " If we feed them, we do not feed on them: a principle of Huaulu taboo and its application », Ethnos, 57 (III-IV), pp. 149-167.

VANDER VeLDEN Felipe

2010 Inquietas companhias: sobre os animais de criação entre os Karitiana, tese de doutorado, Unicamp, Campinas.

VILAÇA Aparecida

1992 Comendo como gente: formas do canibalismo Wari', Editora da UFRJ, Rio de Janeiro.

$2000 \quad$ «O que significa tornar-se outro? Xamanismo e contato interétnico na Amazônia », Revista Brasileira de Ciências Sociais, 15 (44), pp. 59-72.

Viveiros de CASTro Eduardo

1986 Araweté: os deuses canibais, Jorge Zahar Editor/Anpocs, Rio de Janeiro.

1996 " Os pronomes cosmológicos e o perspectivismo ameríndio », Mana, 2 (2), pp. 115-144.

2002 «O problema da afinidade na Amazônia », in Eduardo Viveiros de Castro, A inconstância da alma selvagem e outros ensaios, Editora Cosac \& Naify, São Paulo, pp. 87-180.

WAGLEY Charles

1988 Lágrimas de boas vindas: os índios Tapirapé do Brasil central, Itatiaia/Edusp, Belo Horizonte/São Paulo. 
YvineC Cédric

2005 «Que disent les tapirs? De la communication avec les non-humains en Amazonie », Journal de la Société des Américanistes, 91 (1), pp. 41-70.

ZweIG Stefan

1999 Fernão de Magalhães: o homem e sua façanha, Record, Rio de Janeiro. 